The Income Tax Compliance Cost

of Corporations in India, 2000-01

Arindam Das-Gupta 


\section{Contents}

Summary

1. Introduction 9

Objective and Scope $\quad 9$

Defining and Measuring the Compliance

Cost of Companies

Conclusions from Earlier Compliance Cost

Studies of Companies

2. Estimation of Compliance Cost: Methodology 15

Basic Estimation $\quad 15$

Mandatory and Voluntary Costs $\quad 15$

Cash Flow Benefits $\quad 16$

Net Compliance Costs and Social Compliance Costs $\quad 17$

Problems with Fixed Cost Apportionment and

Other Taxes

3. The Information Base for the Study 19

Distribution by Gross Income:

Sample Versus Population 20

Measures of Sample Size relative to Population 20

Basic Characteristics of Sample Companies 21

The Choice of Scale Variables 22

Aggregation Methodology 24

4. Compliance Cost Estimates for Surveyed Firms 24

Legal Compliance Costs 24 
Distribution of Companies Costs by Company Size $\quad 25$

The Cost of Delayed Refunds 25

Benefits from Income Tax Compliance Requirements $\quad 26$

Net Compliance Costs 26

An Estimate of the Cost of Delayed

Refunds based on a CAG Report $\quad 27$

Aggregate Estimates $\quad 27$

5. Compliance Cost Characteristics of Surveyed Firms 29

Contribution to Internal Costs of

Various Compliance Activities $\quad 29$

Use of External Advisors $\quad 29$

Cost of Scrutiny and Appeals 31

Mandatory and Voluntary Compliance Costs 32

Cash Flow Benefits of TDS Obligations 33

Main Conclusions 33

6. High Compliance Cost Requirements:

"Hot Spots" 34

Information from the Survey and Focus

Group Meetings $\quad 34$

Comments on Causes of High Compliance
Costs in Focus Group Meetings

7. Conclusions and Suggestions 39

Conclusions $\quad 39$

Reform Suggestions $\quad 43$

Tables $\quad$ 45-63

Appendix 64

a. Response Rate 64

b. Basic Characteristics of Companies
in the Sample

c. Compliance Costs and Company
$\quad$ Size : Tables

d. The Size of Tax Returns and

e. The Tax Cost to Companies of
CAG Audit Objections 
References 


\section{Summary}

This is the first study of compliance costs of income taxation of companies in India. These are costs to companies of obligations under income tax law and in planning to save taxes. Opportunity costs such as when tax refunds are delayed also included. Different cost concepts include social costs, gross versus net private costs and mandatory versus voluntary costs. Gross private costs include both legal expenses and illegal expenses such as bribes by companies on employees, on tax advice and other non-labour expenses.

Estimates here are for the year 2000-01, based on a postal survey of 45 companies throughout India in August-September 2001. The response rate, at 1.15 percent, was disappointing. Since results are based on a small sample, they should be viewed as tentative.

Gross compliance costs for 2000-01 are estimated at between 5.6 and 14.5 percent of corporation tax revenues. The estimates do not include bribe costs. Costs are to those elsewhere if they are near the lower limit but a cause for concern near the upper limit. Tax deductibility of legal expenses and cash flow benefits from the timing difference between taxable income and payment of tax result in net compliance costs of between minus 0.7 and plus 0.6 percent of corporation tax revenue, though these rise to around 2 percent when opportunity costs are included. Net compliance cost estimates do not include an estimate of cash flow benefits of tax deductors. Both gross and net compliance costs are regressive. Furthermore:

- Most companies (62 percent) benefit from compliance requirements as income statements and balance sheets are better prepared. 50 percent find audit requirements helpful in detecting dishonest employees.

- Twelve sample companies paid excess tax (median value: 46 percent of tax due) since tax evasion penalty is not leviable under Indian law if assessed taxes have already been paid.

- Answering qeries during scrutiny assessment and accounting requirements are the most costly activities. 
- 70 percent of companies, especially small companies use external assistance to prepare tax returns.

- External costs account for around 39 percent of the total legal costs of sample companies.

- Compulsory external financial audit is the main source of fees of external professionals. Other important sources are litigation and providing assistance to company employees.

- Voluntary costs are estimated to lie between 19 and 43 percent of total compliance costs.

- The average sample company had 10 to 11 assessment years locked in disputes for tax or penalty. Adding the time for scrutiny assessments, the number of open assessment years of a typical company is 12 to 14 . Statistical analysis suggests that one extra disputed assessment year raises legal compliance costs by 5.7 percent.

- The time taken to close an assessment varies from 2 years if no tax dispute arises to over 20 years if a dispute goes to the Supreme Court.

- Incorrect application of tax laws by tax officials burden taxpayers who have their tax assessments revisited. The most serious problem is with valuation of closing stocks of companies followed by underassessment of tax. Both of these are areas where assessing officers have high discretion.

Reform suggestions include:

- Tackling delayed refunds by streamlining refund procedures and strengthening anti-corruption.

- Improving taxpayer services for business.

- Reducing discretionary powers of income tax officials, increasing individual accountability and reducing occasions for direct contact with taxpayers.

- Regular post facto sampling and review of appeal cases to guard against corruption at this stage.

- Strengthening advance rulings and extending their scope.

- Scrapping selected concessions where they are not matched by commensurate social benefits.

- Reform of 22 legal and procedural "hot spots" which add to compliance costs. 
Estimation problems include qualitative rather than quantitative questions about in-house cost components; assumed rather than the actual opportunity cost of funds to value cash flow benefits; no application of shadow values to estimate social compliance costs; and, as in earlier studies, possible bias due to incorrect apportionment of fixed costs and the value of time of company management.

Sampling problems include a stratified random design that degenerated into a convenience sample; over-representation of large firms; and under-representation of loss making and zero profit companies. 


\title{
The Income Tax Compliance Cost of Corporations in India, 2000-01*
}

\author{
Arindam Das-Gupta ${ }^{* *}$
}

\section{Introduction}

\section{Objective and Scope}

The objective of this study is to measure the cost of compliance with the income tax of Indian corporations and ascertain how these costs compare internationally. Besides aggregate estimates, (a) sources of compliance costs and their break-up in terms of different compliance activities and within sources, legal and illegal compliance costs, (c) determinants of compliance costs in terms of firm characteristics and the importance of mandatory obligations as against voluntary tax planning activity are also studied.

In the next two sub-sections compliance costs are defined and international evidence on compliance costs is reviewed. The study sample is described in section 2. Estimates for the study sample and for all Indian companies are in section 3. The association of compliance costs with characteristics of surveyed firms and components of compliance costs are then examined, in section 4. Section 5 reports opinions of surveyed respondents about high compliance cost or "hot spot" tax code provisions and administrative procedures. In Section 6, conclusions of the study are summarised and reform suggestions are made.

\footnotetext{
This paper is excerpted and condensed from a report on company compliance costs, Chattopadhyaya and Das-Gupta (2002), prepared for the Planning Commission at the National Institute of Public Finance and Policy. The report is available at the Planning Commission website http://www.planingcommission.nic.in/reports.

**:Professor of Economics and Finance, Goa Institute of Management, Ribander, Goa 403006, India. Phone: 91-832-2444638, E-mail: oldmonk87@yahoo.com.
} 


\section{Defining and Measuring the Compliance Cost of Companies}

Overall costs of a tax system include "welfare costs, opportunity costs, psychic costs, social costs and so on"'. To assess the total impact of taxes on society, "the total sacrifice imposed upon the populace - total collection costs, administrative and compliance costs, should be looked into". Slemrod and Yitzhaki (1996) identify compliance costs as one of the five component costs of taxation. The others are administrative costs, deadweight efficiency loss from taxation, the excess burden of tax evasion and avoidance costs. Taxes themselves are merely a transfer of purchasing power from the private to the government sector. Costs that arise in effecting this transfer are what the Slemrod-Yitzhaki analysis points to. Compliance costs of taxpayers are, however, not the only costs. All agents involved in facilitating this transfer of funds from the private sector to the government exchequer incur costs. Such third party costs include, for example, costs of employers responsible for tax deduction at source. Financial institutions collecting taxes also incur third-party compliance costs.

In defining compliance costs of taxation, in this study, all costs due to the tax system borne by taxpayers and third parties other than cost arising from economic distortions and equity violations are included. So both "genuine" compliance costs and avoidance costs are included here as they are hard to distinguish in practice. Though costs of noncompliance, including costs associated with tax evasion, are also included in the definition adopted, in this study no specific information is available on costs due to tax evasion. ${ }^{3}$

For businesses, sources of tax compliance costs in most earlier studies ${ }^{4}$ have been subdivided into in-house personnel costs, other inhouse costs and external costs associated with retaining the services of tax, accounting and legal professionals. Costs include (a) in- house

\footnotetext{
1 See Evans and Walpole (1997).

2 See Mikesell (1986).

3 However, some information is available on costs incurred to forestall accusations of tax evasion. See section 4 and, for case studies, Chattopadhyay and Das-Gupta (2002).

${ }^{4}$ See section 1.3 below.
} 
costs incurred both by tax departments and by other departments, ${ }^{5}$ (b) external costs including bribes and gifts to government officials, (c) "Third party costs", such as tax collection cost of banks and costs of others required to provide information to tax authorities and (d) in principle, costs of non-filing for companies choosing not to file returns. ${ }^{6}$

Costs as defined for this study include mandatory elements and voluntary and quasi-voluntary costs. Voluntary costs are mainly associated with tax planning or avoidance to reduce tax liabilities. The distinction between voluntary and mandatory costs has been made in several earlier studies. ${ }^{7}$

The major activities generating compliance costs of companies include maintaining books of account, complying with tax return filing obligations, obtaining taxpayer identification numbers, clearances and permissions where required by law, tax avoidance or tax planning to reduce tax liability, tax audits (or scrutinies as they are called in India), appeals, court references and tax prosecutions. Also included are costs of discharging statutory tax withholding obligations (tax deduction at source or TDS in Indian parlance). A problem faced by many earlier studies is that the extent to which some activities, such as accounting, are undertaken for tax compliance as opposed to other reasons is hard to ascertain. Of these, a major difficulty is in apportionment of capital costs. Time costs of owners, directors and proprietors have also been found to be difficult to estimate in earlier studies. Compliance costs of the Income tax may also be difficult to

5 That costs outside tax departments can be significant has been documented by Gunz, McNaughton and Wensley (1995) and Porter (1999). The former focuses specifically on costs of tax incentives for $R$ and $D$ which they find to be largely borne by research staff.

6 There are also psychic costs including mental stress suffered by the internal staff or tax advisors, reviewed, for example, in Pope and Fayle (1991). Possibly more important are costs imposed on society by business uncertainty due to frequent changes in tax provisions and tax administration procedures. These are surveyed for individuals and companies in Das-Gupta and Chattopadhyay (2002) and (2002a).

${ }^{7}$ Further discussion is in Chattopadhyay and Das-Gupta (2002a). 
separate from costs for other taxes. ${ }^{8,9}$ As a result, internal costs estimates are subject to a margin of error. ${ }^{10}$

In terms of objects of expenditure, wages, salaries and allowances, stationery and supplies, rents and other overheads, computer hardware and software costs and travel are some of the major items. Acquiring tax knowledge, training costs, and membership fees paid to representative bodies and lobbying for taxation matters are also present.

The discussion so far pertains to gross compliance costs. Net compliance costs are the difference between gross compliance costs and the value of benefits from compliance activities. The tax deductibility of compliance cost expenditure is also taken into account in computing net costs. ${ }^{11}$ The major benefit is from the augmented cash flow due to the time elapsing between tax becoming liable and remittance of tax. This is true both for TDS agents and also for the corporation tax itself. Estimates of these cash flow benefits are sensitive to the opportunity cost of funds assumed, as also to assumptions made about the timing of cash accruals and disbursements. ${ }^{12}$ Benefits also arise from better record keeping and improved management control, though these are difficult to quantify.

Since most monetary compliance costs are deductible, private costs are typically less than the social costs. To arrive at social or real resource costs, tax deductions for compliance expenditure must be added back to gross private costs and bribes, which are inter-agent transfers, must be netted out.

8 Good discussions are in Sandford, Hardwick and Godwin (1989), and Pope and Fayle (1991).

9 However, a case study reported in Chattopadhyay and Das-Gupta (2002) suggests that estimates in this study are largely for the corporate income tax and not for all taxes paid by corporations.

${ }^{10}$ For example, compliance cost estimates for corporations in the USA in Slemrod and Venkatesh (2002) are almost 10 times as high as those in Slemrod and Blumenthal (1996). Part of the reason is a difference in samples.

${ }^{11}$ See Binh, et. al. (2000).

${ }^{12}$ A discussion of this issue is in Pope and Fayle (1991). 
In measuring compliance costs, there is possibly no alternative to taxpayer surveys. Respondent bias and non-response bias have been warned against by Wallschutzky \& Gibson (1993) and all survey based studies are subject to such bias.

\section{Conclusions from Earlier Compliance Cost Studies of Companies}

In all, around 50 studies of compliance costs of companies in around 20 different countries have been conducted since the 1960s. ${ }^{13}$ The studies vary widely in their scope, coverage and methodology adopted. Indian studies include Export Import Bank of India (1998) on the compliance cost of Indian exporters with export and customs procedures and Sridharan (1999) on business compliance costs in India with Central customs and excise duties. However, their estimates, to the extent that they deal with similar costs, differ widely. Furthermore, they do not cover the income tax, which is the focus of this study.

The major conclusions from earlier studies are (a) that compliance costs of corporations are large relative to tax administration costs and (b) that compliance costs are regressive regardless of the measure of size adopted. ${ }^{14,15}$ In fact net compliance costs of large corporations have been found to be negative for corporations in Australia. ${ }^{16}$

Though it is widely believed that simplification could improve compliance by lowering compliance costs, evidence available does not provide unambiguous evidence of this in all cases. ${ }^{17}$ Consequently, tax simplification and reducing compliance costs should be treated as possibly distinct and in certain cases, even conflicting objectives.

${ }^{13}$ Studies are reviewed in Annex 1.1 of Chattopadhyay and Das-Gupta (2002).

${ }^{14}$ Common size measures include employee strength, value of assets - total or fixed, turnover or sales, and different measures of profits.

${ }^{15}$ Costs as a percentage of tax revenue should be treated with caution as tax revenue may change with tax reform without there being any change in the compliance requirements (Sandford and Hasseldine, 1996).

${ }^{16}$ See Binh et. al. (2000) and Walpole et. al. (1999). For evidence of regressivity for the United States, see Slemrod and Blumenthal (1996).

17 Evidence and analysis is in Bardsley (1997), Blumenthal and Slemrod (1996), Mills (1996), Slemrod and Blumenthal (1996), Slemrod and Venkatesh, (2002). 
Furthermore, Blumenthal and Slemrod (1996) point to a trade off between simplicity and other objectives such as fairness and growth facilitation. $^{18}$

Other sources of variation in compliance costs identified in the literature include the nature of business activity, sector, region and country and second, foreign operations of companies which have been found to raise compliance costs in Canada and the United States. ${ }^{19}$

In terms of sources, internal costs account for the bulk of costs. Of these, personnel costs predominate. For example, of internal costs, Slemrod and Blumenthal (1996) find for large US corporations, that 85 percent of costs were internal costs of which 55 percent were personnel costs. Furthermore, of internal costs, 30 percent is due to departments other than the tax department.

Regarding PAYE (Pay-as-you-earn or TDS), Australian and UK estimates of employer's PAYE are similar, at 2.6 percent of tax revenue. Nevertheless cash flow benefits make net compliance costs much smaller (Pope, Fayle, and Chen, 1993).

There is some support for a negative association between voluntary or tax planning costs and tax revenue (Mills, 1996). This is not necessarily the case, however, for mandatory costs.

International evidence of company compliance costs is presented in Table $1 .{ }^{20}$ As a percentage of tax revenue, estimates for the corporation income tax range between 0.36 percent and 28 percent in the table.

\footnotetext{
${ }^{18}$ Further discussion of simplification and tax complexity and additional references are in Chattopadhyay and Das-Gupta (2002a).

${ }^{19}$ See Blumenthal and Slemrod (1996), Erard (1995), Erard (1997a), and (Slemrod and Venkatesh, 2002).

20 Estimates of compliance costs are not strictly comparable due to very different tax systems and serious differences in methods adopted. Further discussion is in Chattopadhyay and Das-Gupta (2002a) and references cited there.
} 


\section{Estimation of Compliance Costs: Methodology}

\section{Basic Estimation}

The basic relation between different compliance cost estimates is given by

Gross compliance costs = Internal (personnel + other) costs + payments

to advisors + bribe costs

$=$ Legal compliance costs + bribe costs .

Estimates of major compliance cost components including internal personnel and non-personnel costs as well as to external costs are taken directly from questionnaire responses. For internal costs, compliance expenditure classified by objects is also directly available as are estimates for attribution of costs to different tax provisions and administrative procedures.

A deficiency in the questionnaire that came to light after the fact is the neglect of the cost of delayed tax refunds. Only aggregate information on these costs are available from CAG (2002). Consequently, compliance costs at the individual company level are underestimated. The additional estimate reported at the aggregate level is:

Adjusted legal compliance costs $=$ Legal compliance costs + the opportunity cost of delayed refunds.

Due to lack of information the preferred compliance cost concept which could not be estimated is:

"True" gross compliance costs $=$ Adjusted legal compliance costs + bribe costs.

\section{Mandatory and Voluntary Costs}

Voluntary costs are taken to be costs associated with tax planning and research, appeals filed by the company (though not appeals filed against the company) and assistance with tax matters to employees. In a second estimate, unallocated or "other" costs are added 
to this. Apportionment of other cost items was not attempted as being too uncertain. For external costs, the classification into voluntary costs and mandatory costs is directly available from questionnaires. Only qualitative information is available for internal costs according to these categories. The estimate reported here apportions internal costs in line with their importance and that of external costs.

\section{Cash Flow Benefits}

Companies derive monetary benefits from interest savings or earnings due to, first, the timing of advance tax instalments and, second, the time interval between withholding of taxes for employees or nonemployees and deposit of withheld taxes in the government treasury. For tax instalments, it is assumed that instalments correspond to legally laid down percentages and that they are remitted on the due dates. For the opportunity cost interest rate, it was seen that most Indian companies are highly leveraged. ${ }^{21}$ For a leveraged company, higher cash flow will result in a reduced need to borrow resulting in interest cost saving at the marginal borrowing rate of the company. So cash flow benefits are valued at an assumed annual, short term, marginal borrowing interest rate of 15 percent per year, compounded weekly, after discussion with bank officials and a private sector company case study.

For TDS, there is a gap of 6 days for most companies between monthly payment of salary and wages to employees and depositing withheld taxes with the government. For non-employees, an average gap of 15 days was suggested by the case study company. So companies are assumed to derive cash-flow benefits equal to 6 or 15 days of interest saving per month on the monthly amount of tax deducted at source. So the following formula is used to estimate cash flow benefits from TDS by companies:

Cash flow benefit from TDS $=$ [TDS for employees $]\left[\frac{6}{365}\right] 0.15+[$ TDS for non-employees][ $\left.\frac{15}{365}\right] 0.15$.

${ }^{21}$ For example, the average debt equity ratio in 2000-01 of the 5599 companies for whom this information is available in the CMIE's PROWESS data base was 3.23. 
For advance corporation tax, it is assumed that the benefit accruing to companies is the interest saving it achieves compared to if it were required to pay corporation tax on a weekly basis. 4 quarterly advance tax instalments are payable on the 15th in the months June, September, December and March of the financial year. The financial year is from April 1 to March 31. The respective instalments are 15, 30, 30 and 25 percent of the estimated taxes due for the year, excluding any taxes withheld by others on behalf of the company. The timing of these payments makes it clear that taxes due are less than would be the case if taxes were payable weekly, except during the last two weeks of December and March. The formula used to estimate cash flow benefits from the timing of corporation tax payments $(\mathrm{Y})$ is:

$$
\begin{aligned}
& Y=X\left[\frac{\left(1+\left(\frac{0.15}{52}\right)\right)^{52}-1}{\left(\frac{0.15}{52}\right) 52}\right]-X\left[0.15\left(1+\left(\frac{0.15}{52}\right)^{41}\right)+0.3\left(1+\left(\frac{0.15}{52}\right)^{28}\right)\right. \\
& \left.+0.3\left(1+\left(\frac{0.15}{52}\right)^{15}\right)+0.25\left(1+\left(\frac{0.15}{52}\right)^{2}\right)\right] \\
& \text { or } Y=0.01853 X
\end{aligned}
$$

In the equation above, $\mathrm{X}$ is the total corporation income tax due from the company for the year net of tax deducted at source by other entities. Due to the assumed rather than actual opportunity cost of funds and the assumed rather than actual advance tax payments, this formula only approximates cash flow benefits.

\section{Net Compliance Costs and Social Compliance Costs ${ }^{22}$}

From legal compliance costs estimated directly from questionnaires, actual or net compliance costs borne by companies is worked out by taking account of tax deductibility of legal compliance cost expenditures and cash flow benefits. Tax deductibility is assumed to reduce costs at the surcharge inclusive corporation tax rate of 38.5

22 Some of the concepts in this section are discussed in Binh et. al. (2000), which has influenced the definitions adopted here though the two sets of definitions are not identical. 
percent in 2000-01..$^{23}$ Therefore:

Net compliance costs $=$ Legal compliance costs [1-corporation tax rate] +Bribe costs + Opportunity cost of delayed refunds - Cash flow benefits

For social compliance costs, the correct measure should value the real resources expended on tax compliance, regardless of who bears the costs. Bribes, being merely a transfer between different entities should be netted out. Second, however, delayed refunds are available to the government during the period of delay. The appropriate resource cost valuation is, therefore, the difference between the government's short term rate of return on borrowed funds, since the fiscal and revenue deficits of the government in 2000-01 were positive, and the private rate of return. The government's marginal cost of borrowing averaged 9.76 percent per annum in 26 auctions of 364 day treasury bills (Reserve Bank of India, 2001). The resource value of delayed refunds is assumed to be the difference between the assumed 15 percent rate of interest for the private sector and 9.76 percent on an annualized, compound, basis. So the following estimate is reported. ${ }^{24}$

"Social" compliance costs = Legal compliance costs + Resource cost of delayed refunds.

${ }^{23}$ For companies whose marginal tax rate is determined by the Minimum Alternate Tax (MAT), the surcharge inclusive marginal tax rate is $33 \%$. This is taken into account. Foreign companies taxed at a higher rate, were not present in the sample.

${ }^{24}$ Resources could not be valued at their shadow values due to data limitations. Shadow values will differ from market prices in labour surplus economies like India's, with additional differences arising from administered prices, protective tariffs, cascading central excise and state sales taxes and other policy induced distortions. To do the shadow valuation exercise, it is necessary to separate out wage and salary costs for both internal costs and the labour component of external costs. Furthermore, non-labour costs, internal and external, should be divided into the cost of traded goods, and nontraded goods and services. Since labour needed for tax compliance work is largely scarce skilled labour, the shadow wage rate is likely to exceed the market wage. However, non-labour costs are likely to be overestimated relative to resource costs for both traded goods (at border prices) and non-traded goods and services. 


\section{Problems with Fixed Cost Apportionment and Other Taxes}

Since the study aims to estimate the compliance costs of companies only for the income tax (corporation tax and TDS), bias will result if information furnished by companies is not attributable only to the income tax. As discussed, important sources of possible bias are apportionment of fixed costs and the value of time of company management. However, the private sector company case study and other anecdotal evidence suggests that bias due to inclusion of taxes other than the corporation tax may be limited due to organisational separation of responsibilities for the corporation tax and other taxes in major companies. ${ }^{25}$

\section{The Information Base for the Study}

Information on compliance costs for this study was obtained from a mailed survey supplemented by case studies and information on sources of costs from pre-survey focus group meetings. To increase the chance of unbiased responses to questions dealing with bribes and illegal costs, the questionnaire was anonymous and not serially numbered or otherwise identified, despite this making follow-up contact with non-respondents impossible. ${ }^{26}$ Nevertheless, only limited information on bribes and legal costs was obtained. ${ }^{27}$

${ }^{25}$ For a related finding see Blumenthal and Slemrod (1995).

${ }^{26}$ Detailed discussion of the questionnaire and its construction is in Chattopadhyay and Das-Gupta (2002)

27 Analysis of illegal costs is in Chattopadhyay and Das-Gupta (2002). Eight of 14 companies, or over 50 percent of companies expressing an opinion, felt that companies in similar businesses paid bribes to income tax officials. The 70 percent "no comment" rate suggests that the actual percentage could be higher. However, only two companies providing estimates of cash bribes and these were small relative to sales or profits but large relative to the legal income of tax officials. On the other hand, bribes reported as a percentage of tax saved (by 3 companies) suggest substantial bribes and substantial benefits from bribes. 
Among secondary sources, information from reports of the Comptroller and Auditor General (CAG) ${ }^{28}$ were used to (a) estimate the cost of delayed refunds, (b) examine the extent and nature of assessment errors by the Income-tax Department, and (c) arrive at an estimate of the size of the universe for this study (consisting of companies in the year 2000-01). The commercially available PROWESS data base on Indian companies compiled by Centre for Monitoring the Indian Economy $(\mathrm{CMIE})^{29}$ was used for estimates of aggregate compliance costs of companies in India.

\section{Distribution by Gross Income: Sample Versus Population}

The available sample consists of 44 private sector companies. ${ }^{30}$ This represents a disappointing $1.15 \%$ response rate of companies sought to be surveyed (further information is in the Appendix). So an assessment of the representativeness of the sample, however poor, is crucial. Information on the distribution of 3,34,261 (public and private sector) company assessees in terms of returned income or loss is available in CAG (2002) for the year 2000-01, the year to which sample data pertain, for four income groups, which combine both profitable and loss making companies. A comparison between CAG and sample income figures in Table 2 provides the some indication of the representativeness of the sample.

Compared to the CAG distribution, the sample distribution has an over-representation of large firms. Inferences from the sample for smaller firms are likely to be less reliable than for large firms. Information on the distribution of firms by turnover, book value of assets and profit or loss is given in the Appendix.

\section{Measures of Sample Size Relative to Population}

CAG (2002) reports the Department of Company Affairs figure of a population of 569,100 Indian companies in 2000-01. This reduces to 564,916 after subtracting 2918 non-profit associations registered under

${ }^{28}$ See Comptroller and Auditor General (2002) and Comptroller and Auditor General (2002a).

${ }^{29}$ See Centre for Monitoring the Indian Economy (2002).

30 The one public sector company which responded is included as a case study in Chattopadhyay and Das-Gupta (2002) 
the Companies Act and 1266 public sector companies. However, not all of these companies have productive, taxable, activity. CAG (2002) reports only 3,34,261 company assessees on the tax rolls. Finally, if all public sector firms are tax assessees, then the relevant private sector population for this study is 332,995 . This implies a study sample of between 13 and 14 per 100,000 companies.

By other indicators, the size of the sample is somewhat less unsatisfactory. Compared to the CMIE sample, Table 3 shows that a larger proportion of relevant financial aggregates is covered by the sample in contrast to the small number of companies. Overall, therefore, while the sample size is may be inadequate for reliable statistical inference, especially for smaller firms measured by reported income, sample statistics suggest that results are worth reporting if treated as preliminary and viewed with caution.

\section{Basic Characteristics of Sample Companies}

Basic information about sample companies in terms of location, size and age are in the Appendix. Sample biases suggested by the information there are: a disproportionately large number of (a) companies from Mumbai; (b) labour intensitive companies; (c); manufacturing companies; besides (d) as mentioned, large companies with more than 1000 full time employees. On the other hand: (a) no hotels, restaurants or real estate service companies responded to the survey; (b) loss making and zero profit companies are underrepresented.

Data on tax payments and effective tax rates are in Table 4. Given that tax paid during the year is partly for previous years, some tax rates in the table are above the surcharge inclusive corporation tax rate for Indian companies of 38.5 percent in 2000-01. ${ }^{31}$ The other notable feature in the table is the high variability of tax as a percentage of profit

\footnotetext{
${ }^{31}$ Effective tax rates greater than $100 \%$ can arise, since companies were asked to report taxes paid during not for the year. For companies subject to Minimum Alternate Tax on the book value of assets, the effective surcharge inclusive marginal tax rate, for MAT in excess of corporation tax paid, was 33 percent in 2000-01.
} 
before tax, as shown by the standard deviation. ${ }^{32}$

\section{The Choice of Scale Variables}

Compliance costs in current rupees convey little information about their burden. To facilitate inter-company and inter-country comparison, in earlier studies compliance costs are reported as a proportion of gross fixed assets, sales/turnover or employment. All three are reported below. In addition, if compliance costs are interpreted as a "hidden tax", the ratio of compliance costs to profit before tax (PBT) provides the implicit "effective hidden tax rate" and allows the incidence of compliance cost inclusive corporation taxes to be examined. A problem in using PBT arises for loss making companies. Loss making company ratios are reported separately. The fifth, vital, standard of comparison is corporation tax paid. This is because corporation tax compliance costs are a component of the cost of collecting these taxes. However, here too a problem arises with negative taxes, tackled in the same way below as for loss making firms.

In Figure 1, variations in (log) compliance costs with (the log of) these five scale variables are graphed. The compliance cost variable is legal compliance costs. As can be seen, PBT and employment are poor predictors of compliance costs.

\footnotetext{
${ }^{32}$ In a linear regression of taxes paid on profit before tax or loss, the "marginal corporation income tax rate" turns out to be 27.4 percent for sample companies ( $t$-value $=16.6, R$ square $=0.893$ ). This is below both the statutory corporation tax rate for Indian companies and the surcharge inclusive MAT rate.
} 

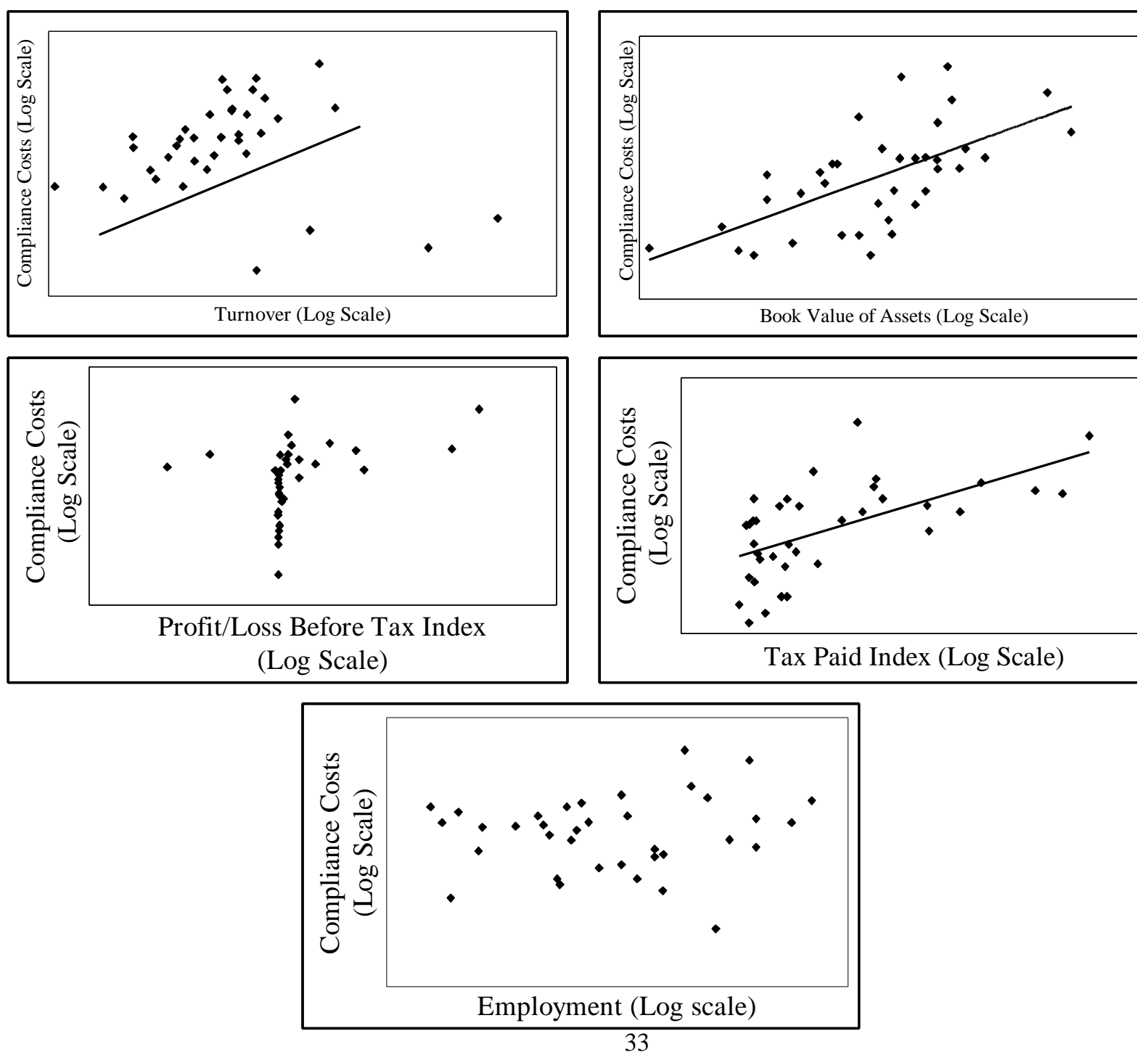

Figure 1: Legal Compliance Costs Versus Indicators of Size 


\section{Aggregation Methodology}

Aggregate estimates use the sample legal compliance cost to turnover ratio and, alternatively, the legal compliance cost to book value of assets ratio. Group means for different size groups are multiplied by PROWESS group means for turnover or book value of assets. A weighted average is then formed using PROWESS sample proportions. Rupee figures are obtained by using tax data from PROWESS and the ratio of tax paid by PROWESS companies to the government budget figure for corporation tax collection in 2000-01 (Rs 357 billion). Besides estimates based on group means, "high" and "low" estimates based on a truncated 5 percent confidence intervals are also reported. A similar exercise was carried out for net compliance costs. Social compliance costs are estimated only at the aggregate level by adding the estimated social cost of delayed refunds to legal compliance costs. ${ }^{33}$

\section{Compliance Cost Estimates for Surveyed Firms}

\section{Legal Compliance Costs}

Gross legal compliance costs are in Tables 5 and 6 for profitable and loss making firms separately. The large coefficients of variation, even after excluding large valued outliers, show that no scale variable is a reliable predictor of these costs. While for some firms, costs are extremely high by international standards, on average they are reasonable except as a percentage of tax paid and per employee. The former is more an indication of the comparatively porous Indian corporation tax than the burden of compliance costs. Nevertheless, the internationally high ratio to tax does indicate that the corporation tax is an expensive source of government finance. The cost per employee, at around 40 percent of India's per capita GDP in 2000-01, is clearly unacceptable. Given the small sample size and high coefficients of

33 Detailed discussion and tables relating to the aggregation methodology are in Chattopadhyay and Das-Gupta (2002). 
variation, these conclusions should be taken as tentative and subject to confirmation with a larger sample of companies.

\section{Distribution of Compliance Costs by Company Size}

Information on costs in relation to the five scale variables is in the Appendix. Though coefficients of variation are still large, and though trends are not monotonic, even after grouping observations, compliance costs are broadly regressive by all indicators of firm size. In particular, costs per employee and as a percentage of tax are unacceptably high for smaller companies, suggesting that reforms to lower compliance costs will help restore the competitiveness of smaller companies whose competitiveness is clearly distorted by compliance requirements.

Findings from statistical analysis of the association of company size with compliance costs are reported in Table $7 .^{34}$ Statistical analysis confirms that legal compliance costs are regressive with respect to all size variables, with regressivity being particularly pronounced for the income variable, profit before tax.

\section{The Cost of Delayed Refunds}

In the sample, 12 companies reported payment of excess taxes. The reason given by the private sector case study company is due to tax evasion penalty not being leviable under Indian law if taxes assessed have already been paid. ${ }^{35}$ Refunding of overpaid taxes involves long delays by the Income-tax Department and the interest rate paid by the government (8 percent simple interest per annum in 2000-01) is at a rate below the opportunity cost of funds of most companies (assumed to be 15 percent per annum compounded weekly as explained in the previous section). The opportunity cost of these blocked funds at current interest

${ }^{34}$ The goodness of fit was better for double-log regressions than for linear regressions with comparable $\mathrm{R}$ squared statistics.

${ }^{35}$ In the Allingham-Sandmo (1972) model, overpayment of taxes to avoid penalty can be an expected income maximising strategy, in the absence of refunds, if and only if tax evasion is not expected income maximising. However, with uncertainty about the extent of overpayment required to avoid penalty, quasi mandatory compliance costs in terms of the net interest (or opportunity) cost of delayed refunds implies that both tax evasion and overpayment of taxes can simultaneously be income maximising. 
rates, given the interest differential, works out to Rs 81.58 per year per Rs 1,000 of refund due. The median value of refunds due was 46 percent of gross taxes or Rs 840,000 and ranged between 1.5 percent of gross tax and 1160 percent of gross tax. The cost of delayed refunds is clearly substantial, especially for companies near the average or above it. However, no survey data are available on the duration of delay.

\section{Benefits from Income Tax Compliance Requirements}

Besides cash flow benefits from compliance requirements, there are also qualitative benefits found in earlier studies. Though hard to value, respondents opinions about these benefits are reported in Table 8. As the table shows, 62 percent of companies reported income statement and balance sheets being better prepared due to compliance requirements while over 50 percent found auditing requirements useful in detecting dishonest employees. Surprisingly, only 23 percent of companies felt that there were cash flow benefits.

\section{Net Compliance Costs}

Estimates of net compliance costs in Table 9 only net out cash flow benefits from the timing of advance tax payments and the tax deductibility of compliance expenditure. Adequate information on TDS cash flow benefits and the cost of delayed refunds are not available. Nevertheless, the estimates presented here are unexpected. Tax deductibility and cash flow benefits reduce legal compliance costs by 86 percent. ${ }^{36}$ In terms of their distribution, net compliance costs turn negative for large firms measured by book value of assets or turnover (see Das-Gupta and Chattopadhyay, 2002). This is similar to the pattern of net compliance costs found in Australia.

Estimates of cash flow benefits from TDS are only available for 5 firms. If cash flow benefits from TDS are also taken into account net compliance costs reduce further (Table 10), though the additional benefit is relatively small.

${ }^{36}$ Once again, averages are to be viewed cautiously given large coefficients of variation, especially for net compliance costs as a percentage of legal compliance costs. 
No estimate of social compliance cost can be made for the sample, as necessary information on delayed refunds is not available.

\section{An Estimate of the Cost of Delayed Refunds Based on a CAG Report}

CAG (2002a) provides information on delays, in months, by the Income-tax Department in granting refunds after the end of the relevant assessment year according to different categories and by the state where the company is assessed. The major category, contributing over 80 percent of delayed refund costs, is delay in the issue of refund vouchers. Since no information is available on the time elapsing between tax payment by the company and the end of the assessment year, this cost element is perforce ignored. The estimate also exclude quasimandatory costs of risk insurance against penalties and possibly also a part of mandatory costs, for example if a refund arises due to excess taxes withheld by others. So estimates given here underestimate actual costs. If it is (again conservatively) assumed that refunds arise due to tax over-payment, the mandatory compliance cost element in delayed refunds will be reflected in CAG data.

The formula used to value the cost of delayed refunds is $\mathrm{W}[1+\mathrm{nr}$ $\left.-\left(1+r_{m}\right)^{n}\right]$, where $r$ is the rate of simple interest paid by the Income-tax Department (8 percent per annum), $r_{m}$ is the opportunity cost interest rate of the company ( 15 percent), $n$ is the period of delay, and $W$ is the amount of refund in rupees. The number (or fraction) of years, $n$, is calculated for each category in CAG data as a simple average of upper and lower limits of the delay, measured in months, for different Indian states. Results of this exercise are given in Table 11. To estimate the social cost of delayed refunds a compound interest rate of 9.76 percent for the government is taken instead of $\mathrm{nr}$.

\section{Aggregate Estimates}

Aggregate estimates are reported in Table 12. The aggregate estimates assume that costs of companies not in the PROWESS private sector data set, including all public sector companies, are similar in terms of the scale variables (turnover and gross fixed assets) as included companies. This needs to be rectified in future research. 
The lowest estimates for different compliance cost measures and the highest show wide variation. Furthermore, confirming their preliminary nature, estimates using gross fixed assets and turnover have only a small overlap.

In the table, legal compliance costs are between 4.33 and 13.18 percent of taxes paid. Adding the cost of delayed refunds, compliance costs rise to between 6.44 and 15.29 percent of taxes. The upper estimate is high by international standards, but, surprisingly, lower than recent estimates for Australia and the United States reported in section 1.

On the other hand, while not all companies have negative net compliance costs, estimates of net compliance costs in the table suggest that, in aggregate, companies are able to recover legal compliance costs despite the under-estimation of cash flow benefits. However bribe costs not being reflected works in the opposite direction. ${ }^{37}$ The addition of delayed refund costs returns all estimates to positive territory.

Both social compliance costs and, after adding administrative costs, gross operating costs, are around 0.5 percent below adjusted legal costs.

The findings of this analysis of company compliance costs are summarised in the concluding section. The major conclusion is that social costs are moderate by international standards at the lowest estimates but high if the higher estimates are correct. Net private costs can be reduced (on average) to zero, if the problem of delayed refunds is tackled. To reduce compliance costs, administrative corruption must be curbed and administration of refunds streamlined. The fragile nature of these estimates, given the small sample size and high variation within the sample are worth pointing out again.

37 The cost of delayed refunds is largely an indirect outcome of corruption. The private sector company case study and qualitative information, suggest that delayed refunds are only partly due to procedural hurdles and the need to window dress collections to meet revenue targets. Reduction in delay can be achieved on payment of bribes at the going rate of 10 percent in many cases. That bribes demanded are more costly than the expected cost of waiting for refunds explains why many companies do not pay bribes to expedite refunds. 


\title{
V. Compliance Cost Characteristics of Surveyed Firms
}

\begin{abstract}
A full scale statistical analysis of determinants of legal compliance costs was attempted but is not reported since the limited sample size, often further curtailed by missing observations, resulted in high standard errors or omission of many variables of interest. Nevertheless, one result worth reporting is that companies which claimed harassment by the Income-tax Department had significantly higher compliance costs than others, after controlling for other legal compliance cost determinants.
\end{abstract}

\section{Contribution to Internal Costs of Various Compliance Activities}

Company opinions on the importance of different compliance activities are reported in Table 13. Additional information asked during scrutiny assessment, followed by maintaining accounts are the major contributory factors. The latter reflects differences in accounting requirements for tax purposes and to satisfy disclosure requirements under the Companies Act. The low importance of tax planning and research and tax training accord with previous studies, but should be treated with skepticism, given probable respondent bias.

Turning to objects of expenditure (Table 14), the small share of expenses on employees does not accord with international experience, but is plausible in a low wage economy like India's. The importance of other items accords with expectations, though the high coefficients of variation and minimum-maximum ranges should be noted.

\section{Use of External Advisors}

Table 15 shows that 70 percent of companies use outside tax advisors to prepare returns, with small companies being somewhat more dependent on external assistance. Tasks entrusted to tax advisors other than return preparation form the bulk of work of tax advisors with fees 
paid to them for return preparation accounting for only a fifth of the total (Table 16). Comparing Table 16 with Table 14, external costs are seen to account for around 39 percent of the total legal costs of sample companies. This is similar to the general pattern in most developed countries. The average share of advisor fees amounts to 42 percent of legal compliance costs (Table 17), implying a skewed distribution with smaller firms making greater relative use of external professional services. ${ }^{38}$ As expected, compulsory external financial audit is the main source of fees of external professionals. ${ }^{39}$ Other important sources of income for advisors are litigation, particularly for cases by the company and, unexpectedly, providing assistance to employees. Research and tax planning, in contrast, is unimportant though, as with internal costs, respondent bias cannot be ruled out.

Regarding the distribution of fees, Table 18 shows that fees paid to advisors are only poorly predicted by company size, especially when size is measured by number of employees rather than turnover. However, in relation to turnover, the rate of increase in advisor's fees is less than proportionate.

Finally, an important issue addressed in Table 19 is: "Why should external expertise be relied on rather than developing in-house expertise?" While the obvious and correct answer is the cost advantage of doing so, the table seeks to ascertain what the sources of this cost advantage could be. The most important reason turns out to be tax instability followed by tax ambiguity or complexity. Even administrative obstacles are less important reasons for engaging tax advisors. Tax planning, as before, is the least important reason for seeking professional assistance.

38 The average across companies is equivalent to a weighted average, with weights being the shares of companies in total fees paid by all companies to advisors.

39 Only $31 \%$ of sample companies separately reported using external professionals for compulsory audits with other respondents not providing the break up of external costs. In fact, this should be $100 \%$. On average $40 \%$ of costs were left unallocated by respondents. 


\section{Cost of Scrutiny and Appeals}

That scrutiny costs are felt to be the most burdensome component of internal costs has been reported above. Scrutiny assessment and appeals are also important sources of external costs. One reason for this is the long delay in completing scrutinies and the large number of appeals filed. Anecdotal evidence suggests that (second) appeals are mainly filed by the Income-tax Department, though statistics on this are not available. Appeals are filed despite reportedly low success rates of the department, so as to avoid sanctions for lack of due diligence during external audit by the CAG, and consequent "passing the buck". During 2000-01, there were 183,340 pending company assessments out of a total workload of 481,702 assessments, which is about 50 percent more than total company assessees. Of these, 30,301 were scrutiny assessments. While no break up is available by company and non-company cases, 292,266 income tax appeals and court cases were pending, or one for every hundred income taxpayers. There were also 210,665 fraud and tax evasion penalty cases and 12,793 prosecution cases pending, Counting both convictions and compoundings as successes, the success rate of the Department in prosecution cases has averaged 31.2 percent during the past 5 financial years. No data are available on the appeals success rate. Clearly, the major outcome of disputes is compliance costs imposed on taxpayers and even greater costs to society without much return in terms of additional revenue.

In the sample, 23 of 37 responding companies (62 percent) were scrutinised. This is a high rate internationally and also in comparison with scrutiny of individuals. Table 20 is startling, and documents the 10 to 11 assessment years in dispute for tax or penalty for the average sample company with a maximum of 20 years. ${ }^{40}$ If the two to three years it takes for completion of scrutiny assessments are added to this, the number of

40 CAG (2002) does not provide separate details for the corporation and personal income tax. For all assessees, the expected duration of cases in 2000-01 ws 37 months in the ITAT, 42 months in high courts and 36 months in the Supreme Court. Weighting expected durations by the proportion of cases at different levels (i.e. pending Supreme Court cases for the current year, high court cases of 4 years ago and ITAT cases of 7 year ago), the expected duration of a tax dispute can be estimated at 58 months. This is considerably less than information presented later for company cases suggests, implying shorter expected durations for non-corporate cases. 
open assessment years of a typical company turns out to be 12 to 14 . This is unacceptable by any reasonable standards. ${ }^{41}$

However, the link between pending assessment years and compliance costs is not statistically robust in statistical exercises reported in Table 21. Going by the most significant result in the table, where the size variable is the profit before tax index, a one year increase in the number of disputed assessment years, results in legal compliance costs increasing by 5.68 percent. ${ }^{42}$ Substantial reduction in both legal compliance costs and social operating costs appear possible if appeal and case filing policies of the Income Tax Department are made cost effective.

\section{Mandatory and Voluntary Compliance Costs}

Voluntary costs are taken to include costs of research and tax planning, of appeals filed by the company and of providing assistance to employees. Quasi-voluntary costs associated with procedures to obtain concessions are excluded, since tax planning has already been accounted for. For external costs, information on these expenditures is available in rupees directly from the questionnaire. For internal costs, only the importance of different costs on a five point scale is available in Table 13. So these costs are estimated using reported scores and the proportion of external costs. ${ }^{43}$ Table 22 suggests that the bulk of costs

${ }^{41}$ The average times taken to close an assessment reported in a case study were as follows:

\footnotetext{
Scrutiny assessment 30 months

Typical final assessment with rectifications $\quad 34$ to 38 months

Typical final assessment with first appeal 34 to 46 months

Typical final assessment with second appeal $\quad 82$ to 112 months

Typical final assessment with High Court reference 202 to 268 months

${ }^{42}$ That is, using the average disputed years figure of $7.85+2.63=10.48$ in Table 20 , $5.68=0.595 / 0.1048$.

43 Scores by respondents of activities in Table 13 are used to compute proportionate weights in total costs for each item.. Assuming that where external costs are important, so too are internal costs, if the external cost proportion for an item exceeds the internal cost proportion, the internal proportion is adjusted up to the average of the external and internal proportions (and then weights are readjusted to again add up to 100 percent). The internal cost of an activity is taken to be proportional to these adjusted weights.
} 
are mandatory costs, despite possible upward bias in voluntary cost estimates, with limited variation across firms. Even if all unallocated expenditures are included, the voluntary cost percentage remains below that of mandatory costs. The tentative conclusion is that voluntary costs lie between 19.1 and 43.1 percent of total compliance costs. This accords with information for other countries.

\section{Cash Flow Benefits of TDS Obligations}

No quantitative information is available on the cost of TDS obligations, though information reported below suggests that they are high on a gross basis. On a net basis, taking into account cash flow benefits, some companies are able to recover much of their outlay. Details for 5 companies, in Table 23, show, however, that there is wide variation in the extent of cash flow benefits.

On average, these benefits amount to 14.5 percent of total legal compliance costs or one third of a percent of tax paid.

\section{Main Conclusions}

The major points emerging in this chapter relate to the importance of administrative delays, scrutiny procedures and litigation as sources of compliance costs. These are all well known as problem areas for tax administration. So the oft made point on the need for streamlining of administrative procedures finds additional support here. Other major findings are the importance of tax instability and complexity for seeking external assistance and the lack of importance of tax planning to compliance costs. 


\title{
VI. High Compliance Cost Requirements: "Hot Spots"
}

\author{
Information from the Survey and Focus Group Meetings ${ }^{44}$
}

Respondent opinions (Table 24) and cost estimates (Table 25) for tax provisions identified as "hot spots" or high compliance cost areas by companies are now reported. Tables 26 and 27 report similar information for administrative procedures. The relatively low variability of responses, as measured by the coefficient of variation (except for refunds in Table 27), is striking and contrasts with many other findings in this paper.

As expected, TDS and compulsory audits, figure at the top. The most troubling finding is that compliance costs for claiming export benefits are rated near the top of Table 25 and also receive a relatively high score in Table 24. This suggests that a these concessions are eroded by compliance costs, reducing their effect on export promotion. The high compliance cost of the MAT confirms results in another study. ${ }^{45}$

The other surprise is costs in connection with free trade zones which focus group participants also verified to be of importance. These costs, associated with the need to get repeated clearances, again hampers export growth. Related "hot spots" are compliance with nonresident withholding and newly amended international tax provisions. Alternatives that can be explored to lower compliance costs are better taxpayer education and assistance, for example through improved advance ruling procedures and broadening their scope.

Among administrative "hot spots", refunds, scrutiny assessment, TDS and litigation are, by now, recurrent themes. In Table 28 which summarises responses to open ended questions, however, two other important areas also come to light: Lack of accountability and

${ }^{44}$ Section numbers here reflect sections of the (Indian) Income-tax Act, 1961.

${ }^{45}$ The Alternate Minimum Tax (AMT) in the United States caused compliance costs to rise by $11.5 \%$ for those subject to AMT but increased compliance costs by as much as $136 \%$ for companies not subject to AMT (Slemrod and Venkatesh, 2002). 
transparency in tax administration matters and non-transparent and ambiguous terminology of tax laws. Lack of accountability and the ill effects of administrative discretion have been pointed out by others over the years, without any impact to date on administrative functioning. So too has the need for clear legal drafting. ${ }^{46}$

\section{Comments on Causes of High Compliance Costs in Focus Group Meetings}

These comments, which serve to flesh out the bare bones provided by numbers, made by individuals with long experience "in the trenches", are of great interest. Specific suggestions made by participants are underlined.

\section{General Comments}

(a) A basic malady today of the tax system was the lack of accountability of officials and their unhelpful attitude.

(b) Technical lapses arise due to new procedures not being pre-tested. One example is automatic additional tax for technical defaults under the now repealed section $43(1 \mathrm{~A})$.

(c) An important source of compliance costs is new or unforeseen income tax notifications. In addition, Revenue Department interpretations of new notifications often differed from taxpayers' interpretations leading to court disputes.

(d) Tax simplification by removing exemptions and deductions would help to lower compliance costs.

On problems with Assessment Procedures and Assessing Officers

(e) In many cases the Income-tax Department itself breaks the law.

(f) Assessing officers' (AOs') fear of targets lead to increased compliance costs of taxpayers via "high pitched assessments".

${ }^{46}$ As pointed out earlier, "psychic costs" of the policy environment are analysed in Chattopadhyay and Das-Gupta (2002). 
(g) Multinational companies have to bring vouchers from their head offices [abroad] on a day-to-day basis for income tax assessment, greatly adding to compliance costs.

(h) Recent transfer pricing provisions are likely to give more discretionary power to AOs.

\section{On Advisors and External Costs}

(i) A large proportion of advisors fees go to cover "idle time" spent waiting for appointments, meetings and hearings, often on chairs or benches outside the rooms of concerned income tax officials.

(j) A major reason for taxpayers using professional advisors was for representation before tax authorities.

(k) Tax consultants continue to be used despite "simplification" because nothing changed in the field after high level reforms.

\section{On Tax Deduction at Source}

The TDS compliance burden of companies is high. Companies are not averse to helping revenue collection by deducting taxes from those who otherwise might not have paid - but they were upset by this resulting in criminal liability in case of technical lapses, especially if these lapses were only in the tax department's mind.

To elaborate:

(I) Companies had to go through two assessments, one for income tax and one for TDS.

(m) Great uncertainty resulted from the fact that no time limit on TDS assessments exists unlike income tax audits where there is a 5 year limit on reopening assessments. So, TDS assessment records have to be maintained for at least 10 years.

(n) TDS penalties were often levied on withholders though the fault lay with withholdees.

(o) There were 10,000 to 15,000 cases in $1998-99$ of penalties under Section 201 [making the principal officer of a company liable for TDS defaults] read with Section 221 [on TDS penalties], most of these being unsustainable. 
(p) Prosecutions were often launched after misinterpretation of the law by AOs. Approval of prosecutions often followed the transfer of senior officers aware of the facts.

(q) For prosecutions, all directors of companies were defendants (usually granted bail) who had to be present at sessions court hearings. Non-appearance could lead to non-bailable warrants of arrest.

(r) Sessions judges were usually untrained in tax matters and often referred prosecution cases back to tax authorities leading to delays. Some TDS cases were over 20 years old.

(s) For payments to non-residents under section 195, the rate of TDS was determined case-by-case by assessing officers. To reduce discretion and compliance costs a prescribed uniform rate was needed.

(t) The scheme for rationalisation of TDS proposed in an article in the Economic Times, 18 February, 2001, was good in principle and should be seriously considered.

(u) Firms should be compensated for the tax collection service they provided to the government.

\section{On Costs of Clearances and Permissions}

(v) Obtaining various clearances and prior approvals from income tax authorities and also following up on letters and petitions contributed greatly to compliance costs.

(w) Clearances for immovable property sales under section 230A were a major problem.

(x) Penal provisions for IT Department staff in case of delays in clearances were needed.

\section{On High Compliance Cost Income Tax Provisions and} Notifications

(y) Conflicts with other legislation (such as the Companies Act) included differences in accounting requirements and depreciation provisions increasing business costs.

(z) Procedures connected with amalgamation, merger or de-merger of companies led to considerable compliance costs

(aa).For companies setting up units in free trade zones, the compliance requirements of section $10 \mathrm{~A}$ and $10 \mathrm{~B}$ [for newly established 
undertaking in free trade zones or for exports] led to tax planning costs. In some cases these costs have deterred companies from setting up units in these zones. This hurts exports.

(ab)Problems with section 44AB (compulsory financial audit) receive little attention from the authorities.

(ac) It is difficult for employers to open provident fund accounts for employees because relevant income tax rules are quite different from the provident fund rules. Why different rules by two arms of the government for the same purpose are needed was not clear.

\section{On Appeals and Litigation}

(ad)Up to 90 percent of cases in which assessing officers make additions end up in appeal.

(ae)Time delays in appeals were exacerbated by an inadequate number of benches though additional benches had recently been sanctioned.

(af)The success rates of the Department in appeals and prosecutions was very low. The major outcome of appeals was higher compliance costs.

(ag) Appeals by the IT Department, even when they did not have a proper case, was sometimes because decisions were made by ITAT counsels themselves - who stood to gain from them.

(ah) One reason for the growth in appeals cases was cases between the tax authorities and government companies. These could be settled outside the court system instead of wasting taxpayers' money.

(ai) Refund of appeal fees in case of dismissed appeals should be made mandatory.

\section{On Delayed Refunds}

(aj) Non-refund of excess tax paid but adjustment of refunds due against future taxes was the norm.

(ak)Many man-hours were wasted in collecting refunds.

(al) Lower level officers were over-enthusiastic about meeting revenue targets and did not pay sufficient attention to refunds.

(am) Penal provisions for IT Department staff in case of delays in refunds should be instituted. 


\section{Conclusions and Suggestions}

\section{Conclusions}

Limitations of the sample, questionnaire design and statistical estimates have been carefully pointed out above whenever they arose. Overall, while the sample size is clearly inadequate for reliable statistical inference, especially for smaller firms, results appear to be worth reporting if results are treated as preliminary and viewed with caution, given that this is a pioneering attempt to measure company income tax compliance costs in India. The major conclusions with regard to company compliance costs and the operating cost of the corporation tax are now summarised. 
Summary of Findings on the Income Tax Compliance Cost of Indian Companies (2000-01)

\begin{tabular}{|c|c|c|}
\hline Compliance Cost Measure & Sample Findings & $\begin{array}{l}\text { Projection for All Indian } \\
\text { Companies }\end{array}$ \\
\hline $\begin{array}{l}\text { Legal compliance costs }(\mathrm{LCC})= \\
\text { Internal (personnel + other) costs } \\
+ \text { payments to advisors }\end{array}$ & $\begin{array}{l}\text { Highly variable but unacceptably high } \\
\text { for some firms. Averages: Rs } 6475 \text { per } \\
\text { employee, } 4.12 \% \text { of profit before tax, } \\
30.41 \% \text { of tax paid }\end{array}$ & $\begin{array}{l}\text { Between } 4.33 \% \text { and } 13.18 \% 0 \\
\text { tax paid }\end{array}$ \\
\hline $\begin{array}{l}\text { Distribution of LCC by company } \\
\text { size }\end{array}$ & $\begin{array}{l}\text { By and large, regressive for all } \\
\text { measures of company size }\end{array}$ & No information \\
\hline $\begin{array}{l}\text { Gross compliance costs: LCC + } \\
\text { bribe costs. }\end{array}$ & Not estimated & No information \\
\hline $\begin{array}{l}\text { Adjusted LCC }=L C C+ \\
\text { opportunity cost of delayed } \\
\text { refunds. }\end{array}$ & $\begin{array}{l}\text { Median refunds due to overpayment of } \\
\text { taxes to avoid penalty average } 46 \% \text { of } \\
\text { taxes. }\end{array}$ & $\begin{array}{l}\text { Between } 6.44 \% \text { and } 15.29 \% \text { o } \\
\text { tax paid. Delayed refund costs } \\
2.11 \% \text { of tax paid }\end{array}$ \\
\hline $\begin{array}{l}\text { Cash flow benefits from advance } \\
\text { tax and TDS }\end{array}$ & Over $50 \%$ of legal compliance costs & Not directly estimated \\
\hline $\begin{array}{l}\text { Net compliance costs }=\text { Adjusted } \\
\text { LCC - cash flow benefits from } \\
\text { advance tax and TDS - tax } \\
\text { deduction of compliance } \\
\text { expenditure }\end{array}$ & $\begin{array}{l}\text { Average: } 15 \% \text { of legal compliance } \\
\text { costs. Negative for most large firms. }\end{array}$ & $\begin{array}{l}\text { Between minus } 0.72 \% \text { and } p / c \\
0.62 \% \text { of tax paid before delas } \\
\text { refund costs }\end{array}$ \\
\hline $\begin{array}{l}\text { "Social" compliance costs = LCC } \\
+ \text { social opportunity cost of } \\
\text { delayed refunds }\end{array}$ & Not estimated & $\begin{array}{l}\text { Between } 5.61 \% \text { and } 14.46 \% \text { o } \\
\text { tax paid. Delayed refund socia } \\
\text { cost: } 1.28 \% \text { of tax paid }\end{array}$ \\
\hline $\begin{array}{l}\text { "Social" operating costs }= \\
\text { "Social" compliance costs }+ \\
\text { administrative expenditure }\end{array}$ & Not applicable & $\begin{array}{l}\text { Between } 5.92 \% \text { and } 14.77 \% \text { o } \\
\text { tax paid }\end{array}$ \\
\hline
\end{tabular}


Other important conclusions about compliance costs are:

- While some firms have extremely high compliance costs, on average they are reasonable by international standards.

- Relatively high legal compliance costs as a percentage taxes are more an indication of the porous Indian corporation tax than the burden of compliance costs. Nevertheless, the corporation tax is an expensive source of government finance.

- Estimates of net compliance costs suggest that, in aggregate, companies are able to recover legal compliance costs, though this is not the case for small companies.

- Social costs are moderate by international standards at the lowest estimate but high if the higher estimate is closer to the real situation.

- Many companies find income statements and balance sheets better prepared due to compliance requirements and auditing requirements are found useful in detecting dishonest employees.

- Legal compliance costs are regressive with respect to all size indicators examined.

- Twelve sample companies reported payment of excess taxes since tax evasion penalty is not leviable under Indian law if taxes assessed have already been paid. At the median, overpayment amounted to 46 percent of taxes paid.

Other findings about compliance requirements of companies and compliance cost components are:

- Additional information asked during scrutiny assessment followed by maintaining accounts are the major activities contributing to compliance costs. For the latter, differences in accounting requirements for tax purposes and under the Companies Act are of importance.

- Seventy percent of companies use outside tax advisors to prepare returns, with small companies being somewhat more dependent on external assistance.

- External costs account for around 39 percent of the total legal costs of sample companies.

- Compulsory external financial audit is the main source of fees of external professionals. A second important sources is litigation.

- The most important reason for use of professional advisors is tax structure instability due to frequent changes in tax laws followed by ambiguity and complexity of tax laws. 
- Of legal compliance costs, the bulk consists of mandatory costs, with voluntary costs being estimated to be between 19 and 43 percent of legal costs.

- The average sample company had 10 to 11 assessment years locked in disputes for tax or penalty with a maximum of 20 years. Given two to three years for scrutiny assessments, the number of open assessment years of a typical company is 12 to 14 .

- Statistical analysis suggests that a one year increase in the number of disputed assessment years, raises legal compliance costs by 5.68 percent.

- Sample information points to over 50 percent of Indian companies paying bribes to income tax officials

\section{Reform Suggestions}

General suggestions are first made followed by a list of high compliance cost legal provisions and administrative procedures for which streamlining by the Income-tax Department is suggested.

General suggestions

- Private compliance costs, on a net basis can be reduced, on average, to zero, if the problem of delayed refunds is tackled by streamlining refund procedures and reducing the time lag. Administrative corruption in this area should also be tackled.

- Improving taxpayer services for business appears to offer scope for reducing compliance costs of high cost provisions.

- To reduce compliance costs, reducing the discretionary powers of income tax officials, increasing their individual accountability and reducing direct contact with taxpayers where possible are important.

- Among specific areas, alleged bribe taking by appellate authorities to give favourable judgments could be guarded against, by regular after the fact reviews of a sample of appeal cases.

- Costs of the policy environment, tax laws and frequent administrative notifications are high and require reduction.

- To reduce costs of complexity and ambiguity, tax law simplification, including improved legal drafting, is indicated.

- Strengthening advance rulings and extending their scope can also reduce costs of tax ambiguity and complexity. 
- Efforts to harmonise central and state tax provisions, such as regarding notified backward districts, can also lower compliance costs.

- There are five areas related to international transactions that are troublesome (identified below). These areas will become increasingly important as global links of Indian companies grow.

\section{Reform of Specific Provisions}

Legal and procedural "hot spots" which add to compliance costs are listed below. Besides detailed examination by the Income-tax Department and simplification where possible, improving taxpayer services for business appears to offer the best scope for reducing compliance costs of these provisions. However, with regard to concessions, the large tax benefits companies derive from them suggest that tax simplification by scrapping concessions, especially where the extent of the concession is not justified by commensurate achievement of social objectives, is an additional option for lowering compliance costs. ${ }^{47}$

Legal hot spots include:

- Compulsory financial audit

- Claiming export concessions, with particular reference to rules, clearances and procedures

- Non-resident withholding

- Permissions in connection with free trade zones

- International tax provisions

- The Minimum Alternate Tax

- Valuation of perquisites

- Provisions related to company restructuring

- Discretion of assessing officers in applying newly introduced transfer pricing regulations

- TDS penalties for withholders and the absence of a time limit for TDS assessment

${ }^{47}$ Reform of procedures as well as tax simplification have both been suggested by the Kelkar Committee. See Government of India, Ministry of Finance and Company Affairs (2002). 
- Absence of penalties for tax department staff especially concerning delayed refunds and clearances.

Regarding administrative procedures, hot spots identified include:

- Refund procedures and monitoring

- Appeal filing and disposal especially due to the lack of a policy to ensure cost effectiveness and increase the department's success ratio.

- Inadequate tax related expertise of appeals tribunals

- The absence of realistic revenue targets for assessing officers

- The limited accountability of assessing officers. This can be improved by tracking past assessment performance of individual assessing officers. In turn, computerisation of personnel records, including assessment work done by officers, will help.

- Inadequacies in the scheduling of assessment hearings, keeping in vie the convenience of taxpayers, resulting in excessive waiting time of assessees or their representatives.

- The slow speed of scrutiny procedures and separation of TDS and corporation tax scrutinies

- Excessive discretion of assessing officers, for example in setting rates for tax deduction at source under section 194J. One measure to reduce this is by preparing a scrutiny manual which currently does not exist.

- Inadequate training of assessing officers in selected areas identified by audit objections. This can be rectified by focused training, designed after necessary internal inquiry to ascertain the causes of lapses.

- Procedures for grant of tax clearance certificates (Form 34A) under section 230A. 
Table 1: Recent Evidence of Tax Compliance Costs of Corporations (percentages of tax revenue of relevant tax)

\begin{tabular}{|c|c|c|c|c|c|c|}
\hline Country & Year & $\begin{array}{l}\text { Corporation tax/ } \\
\text { income tax }\end{array}$ & $\begin{array}{c}\text { Pay as you } \\
\text { earn } \\
\text { (PAYEE) }\end{array}$ & $\begin{array}{c}\text { Other } \\
\text { business } \\
\text { taxes }\end{array}$ & $\begin{array}{c}\text { Total } \\
\text { compliance } \\
\text { costs }\end{array}$ & $\begin{array}{l}\mathrm{Ad} \text { ' } \\
\text { istri } \\
\mathrm{CC}\end{array}$ \\
\hline Australia $^{1}$ & 1994-95 & $\begin{array}{c}6.8 \\
17.1(\mathrm{~S})\end{array}$ & $\begin{array}{c}1.3 \\
2.5(\mathrm{~S})\end{array}$ & $\begin{array}{c}8.0 \\
11.9(\mathrm{~S})\end{array}$ & & \\
\hline Canada $^{2}$ & $\begin{array}{l}\text { (a) } 1996 \\
\text { (b) c. } 1994\end{array}$ & $4.6-4.9$ & & & & \\
\hline Fed. Rep. of Germany ${ }^{3}$ & $1984-85$ & & & & 9.5 & 2. \\
\hline Hong Kong $^{4}$ & 1987 & 1.5 & & & & \\
\hline$|s r a e|^{5}$ & 1987 & 2.2 & & & & 0.1 \\
\hline Malaysia $^{6}$ & 1994 & 0.36 & & & & \\
\hline & c. 1994 & 4.0 & & & & \\
\hline New Zealand ${ }^{8}$ & $1989-90$ & & 1.3 & 6.3 & 3.9 & \\
\hline Norway $^{9}$ & 1987 & 8.8 & & & & \\
\hline Sweden $^{10}$ & 1993 & $\left(1.7^{7}\right)$ & 0.34 & 2.6 & & 0. \\
\hline $\mathrm{UK}^{11}$ & 1996 & 2.2 & 1.9 & 3.7 & & \\
\hline$U_{S A}^{12}$ & 2000 & $26.9-28.0$ & & & & \\
\hline $\mathrm{USA}^{13}$ & 1992 & 3.2 & & & & \\
\hline RANGE & --- & $0.36-28.0$ & $0.34-1.9$ & $2.6-8.0$ & --- & \\
\hline $\begin{array}{l}\text { Notes and Sources: } \\
\text { 1. Evans et. al. (1997) } \\
\text { tax on businesses. S: S } \\
\text { 2. (a) Plamondon and Z } \\
\text { Erard (1997a). } \\
\text { 3. Tauber (1983) and T } \\
\text { 4. Harris (1989). } \\
\text { 5. Freidkes and Gavish } \\
\text { 6. Ariff et. Al. (1995). } \\
\text { 7. Allers (1995). Imhof } \\
\text { 8. Sandford and Hassel } \\
\text { 9. Nicolaissen (1989). }\end{array}$ & $\begin{array}{l}\text { orted in Binh } \\
\text { ial complianc } \\
\text { sman (1996) } \\
\text { el (1984). } \\
\text { 989). } \\
\text { Snijder (198 } \\
\text { ee (1992). }\end{array}$ & $\begin{array}{l}\text { 0). Estimates are } \mathrm{f} \\
\text { sts. Private compl } \\
\text { opinion survey of }\end{array}$ & $\begin{array}{l}\text { usiness taxp } \\
\text { pliance costs are } n \\
\text { pliance }\end{array}$ & $\begin{array}{l}\text { s and "Corp } \\
\text { tive for larg } \\
\text { mall and } \mathrm{m}\end{array}$ & $\begin{array}{l}\text { tion tax " actu } \\
\text { usinesses. } \\
\text { um business is }\end{array}$ & sorte \\
\hline
\end{tabular}


10. Malmer (1994) and Malmer (1995). "Corporation tax" is actually income tax, including for individuals.

11. Hudson and Godwin (2000), Collard and Godwin (1999). Cash flow benefits exceeded compliance costs for firms w over 1000 employees.

12. USA: Slemrod and Venkatesh (2002) for small and medium businesses. Blumenthal and Slemrod (1992) for large businesses.

Table 2: Distribution of Companies: Population versus Study Sample

\begin{tabular}{lcccccc}
\hline $\begin{array}{c}\text { Income/loss } \\
\text { range in } \\
2000-01\end{array}$ & $\begin{array}{c}\text { CAG } \\
\text { distribution of } \\
\text { companies in } \\
\text { Rs } 000)\end{array}$ & $\begin{array}{c}\text { Sample } \\
\text { distribution of } \\
\text { companies } \\
(\%)\end{array}$ & $\begin{array}{c}\text { Sample } \\
\text { minus } \\
\text { population } \\
(\%)\end{array}$ & $\begin{array}{c}\text { Cumulative CAG } \\
\text { distribution of } \\
\text { companies in } \\
2000-01(\%)\end{array}$ & $\begin{array}{c}\text { Cumulative sample } \\
\text { distribution of } \\
\text { companies (\%) }\end{array}$ & $\begin{array}{c}\text { Sample min } \\
\text { population ( }\end{array}$ \\
\hline $0-50$ & 59 & 20 & -39 & 59 & 20 & -39 \\
$50-500$ & 17 & 5 & -12 & 76 & 25 & -51 \\
$500-1000$ & 12 & 5 & -7 & 88 & 30 & -58 \\
$>1000$ & 12 & 70 & 58 & 100 & 100 & 0 \\
Total & 100 & 100 & 0 & 100 & 100 & 0 \\
\hline
\end{tabular}


Table 3: Indicators of Sample Size

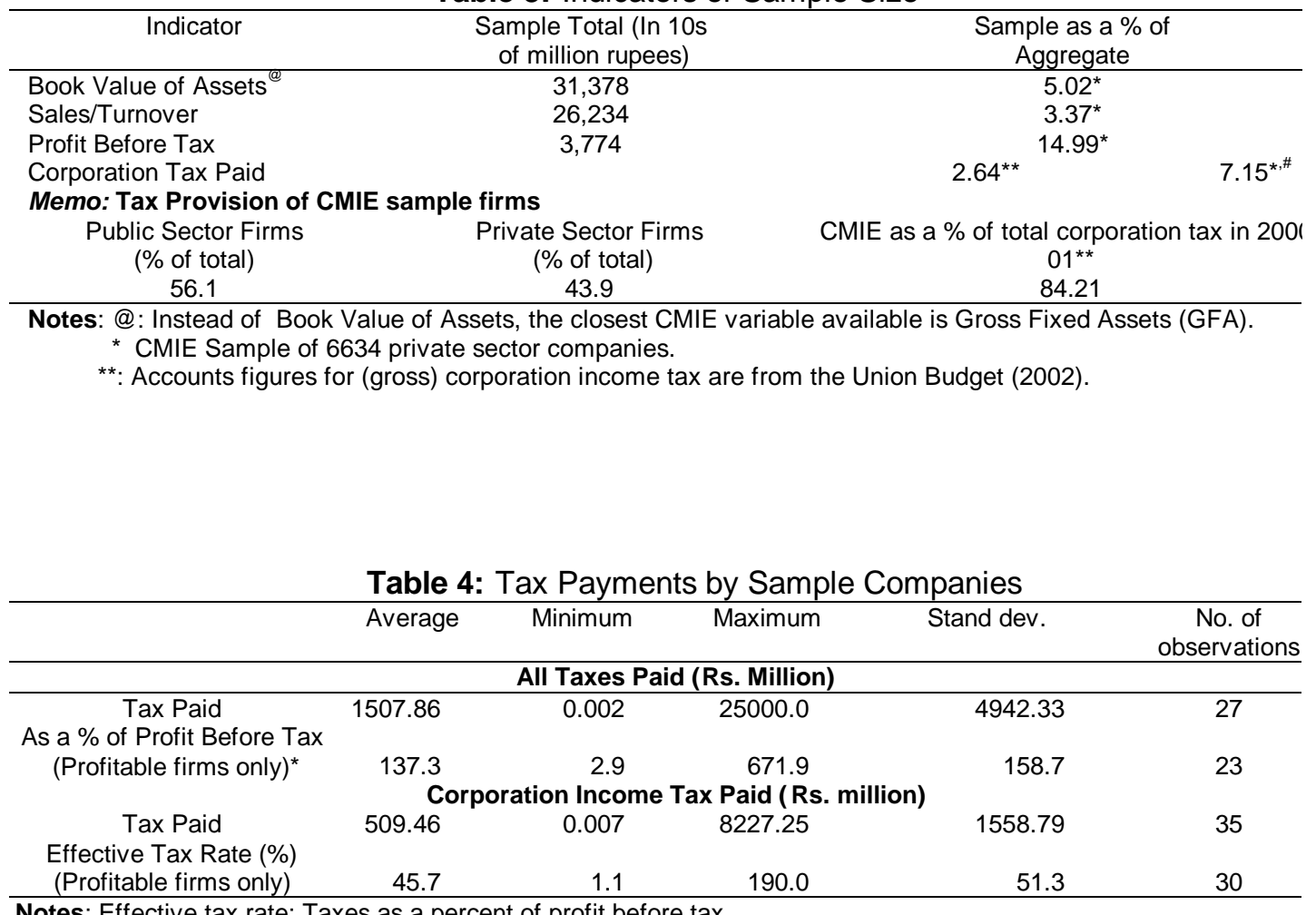

Notes: Effective tax rate: Taxes as a percent of profit before tax.

*Excludes two outliers: 118182.8 and 3165.17. 
Table 5: Estimates of Legal Compliance Costs of Profit Making Units

\begin{tabular}{|c|c|c|c|c|c|}
\hline & $\begin{array}{c}\% \text { of } \\
\text { turnover }\end{array}$ & $\begin{array}{l}\text { Per full time \& } \\
\text { Part time employee } \\
\text { (Rupees) }\end{array}$ & $\begin{array}{l}\% \text { of profit } \\
\text { before tax }\end{array}$ & $\%$ of tax & $\begin{array}{r}\% \text { of book vi } \\
\text { of assets }\end{array}$ \\
\hline Average & 0.35 & 6475 & 4.12 & 30.41 & $1.3 \mathrm{C}$ \\
\hline Minimum & 0.003 & 47 & 0.025 & 0.11 & $0.0 C$ \\
\hline Maximum & 2.07 & 39616 & 30.00 & 392.47 & $7.7 \epsilon$ \\
\hline Standard Deviation & 0.53 & 10278 & 6.33 & 71.58 & 2.07 \\
\hline Coefficien 't of Variation & 1.53 & 2.00 & 1.54 & 2.35 & $1.5 \subseteq$ \\
\hline No of observations & 32 & 30 & 29 & 32 & 31 \\
\hline
\end{tabular}

Note: The table excludes the following outliers (i.e. lying outside average \pm 3 standard deviations).
(a) \% of turnover: 7.72
(b) Per full time \& part time employee: 95,345.
(c) \% of profit before tax: 1363.64 . A zero profit company is also excluded.
(d) \% of tax: 1136.39 .
(e) \% of book value of assets: 17.99 and 10.66 . 
Table 6: Estimates of Legal Compliance Costs of Loss Making Units

\begin{tabular}{lcccc}
\hline & $\begin{array}{c}\% \text { of } \\
\text { turnover }\end{array}$ & $\begin{array}{c}\text { Per full time \& } \\
\text { part time employee } \\
\text { (Rupees) }\end{array}$ & \% of loss & $\begin{array}{c}\text { \% of book value } \\
\text { of assets }\end{array}$ \\
\hline Average & 0.21 & 6501 & 1.71 & 1.43 \\
Minimum & 0.01 & 130 & 0.17 & 0.04 \\
Maximum & 0.55 & 26500 & 4.53 & 5.19 \\
Standard Deviation & 0.21 & 11256 & 1.77 & 2.51 \\
Coefficient of Variation & 1.00 & 1.73 & 1.03 & 1.76 \\
No of observations & 5 & 5 & 5 & 5 \\
\hline
\end{tabular}

Notes: (1) The table excludes the following outliers (i.e. lying outside average \pm 3 standard deviations).

(a) Per full time \& part time employee: $216,667$.

(b) \% of profit before tax: 11.60 .

(c) \% of book value of assets: 43.33 .

(2) Total compliance costs as a \% of tax are not reported because of both positive and negative taxes and high variability. 
Table 7: Legal Compliance Costs and Company Size (Double-Log regressions on Scaled Legal Compliance Costs in Rupees)

\begin{tabular}{lcccrr}
\hline \multicolumn{1}{c}{ Scaling (Size) variable } & $\begin{array}{c}\text { Constant } \\
(' 000)\end{array}$ & $\begin{array}{c}\text { Size } \\
\text { coefficient }\end{array}$ & Elasticity & $\begin{array}{r}\text { R squared } \\
\text { Obser } \\
\text { ation }\end{array}$ \\
\hline Turnover (in Rs) & $1.98^{* * *}$ & $0.441^{* * *}$ & 0.441 & 0.480 & 37 \\
Book Value of Assets (in Rs) & $2.64^{* * *}$ & $0.394^{* * *}$ & 0.394 & 0.441 & 36 \\
Employment (in numbers) & $0.497^{* * *}$ & $0.258^{* *}$ & 0.258 & 0.404 & 34 \\
Profit Before Tax/Loss Index \# & $-0.980^{* * *}$ & $0.303^{*}$ & 0.139 & 0.446 & 21 \\
Net Tax Paid Index\# & $-0.688^{* * *}$ & $0.355^{* * *}$ & 0.285 & 0.147 & 37 \\
\hline
\end{tabular}

Notes: (1) *: Significant at $10 \% ;{ }^{* *}$ : Significant at $5 \%,{ }^{* * *}$ : Significant at $1 \%$.

(2) @: Coefficients are multiplied by 1000 excepting for employment.

(3) Regressions also included the number of assessment years still open, if the variable proved significant at least at $10 \%$

(4) Results for the number of assessment years still open are reported below.

(5) \#: Given negative values of these variables, a linear transformation given by

$$
\mathrm{x}_{\text {index }}=0.1+\frac{\mathrm{x}-\mathrm{x}_{\text {min }}}{\mathrm{x}_{\text {max }}-\mathrm{x}_{\text {min }}} \text { was used. Elasticities are for the basic }- \text { not transformed }- \text { variable }
$$

Table 8: Benefits From Income Tax Compliance Requirements

\begin{tabular}{|c|c|c|c|}
\hline & $\begin{array}{l}\text { Number of positive } \\
\text { responses }(A)\end{array}$ & $\begin{array}{c}\text { Total } \\
\text { Responses (B) }\end{array}$ & $\begin{array}{l}\text { (A) as a \% } \\
\text { of (B) }\end{array}$ \\
\hline $\begin{array}{l}\text { Company's income statement and balance sheets } \\
\text { Are better prepared }\end{array}$ & 28 & 45 & 62 \\
\hline $\begin{array}{l}\text { Better detection of employee malfeasance } \\
\text { (due to requirements under Section } 44 \mathrm{AB} \text { ) }\end{array}$ & 23 & 45 & 51 \\
\hline Cash flow benefits & 10 & 43 & 23 \\
\hline
\end{tabular}


Table 9: Net Compliance Costs (NCC) after Tax Deduction of Compliance Expenditure anc Cash Flow Benefits from Timing of Advance Tax Payments

\begin{tabular}{lcrrr}
\hline & $\begin{array}{c}\text { Cash flow benefits } \\
\text { as a \% of legal } \\
\text { compliance costs }\end{array}$ & $\begin{array}{c}\text { NCC: \% of legal } \\
\text { compliance costs }^{\circledR}\end{array}$ & $\begin{array}{c}\text { NCC: \% of profit } \\
\text { before tax }^{\$}\end{array}$ & $\begin{array}{r}\text { NCC: \% } \\
\text { tax paic }\end{array}$ \\
\hline Average & 85.55 & 14.45 & 2.09 & $23.7 \epsilon$ \\
Minimum & 33.00 & -329.03 & -1.53 & $-1.7 \varepsilon$ \\
Maximum & 429.03 & 67.00 & 18.45 & 269.37 \\
Coefficient of variation & 1.12 & 6.61 & 1.95 & $2.2 \varepsilon$ \\
Number of positive observations & 39 & 30 & 18 & 24 \\
Total Number of observations & 39 & 39 & 29 & 35 \\
\hline
\end{tabular}

Notes: @: Excludes two outliers with \% of legal compliance costs of -1178.61 and -836.60 .

\$: Excludes one outlier: -838.64.

*: Excludes one outlier: 697.28.

Table 10: Legal and Net Compliance Costs of Five Companies

\begin{tabular}{|c|c|c|c|c|c|c|c|}
\hline & $\begin{array}{c}\text { Company } \\
\text { A }\end{array}$ & $\begin{array}{c}\text { Company } \\
\text { B }\end{array}$ & $\begin{array}{c}\text { Company } \\
\text { C }\end{array}$ & $\begin{array}{c}\text { Company } \\
\text { D }\end{array}$ & $\begin{array}{c}\text { Company } \\
\text { E }\end{array}$ & Average & $\begin{array}{l}\text { Coeffic } \\
\text { of varie }\end{array}$ \\
\hline \multicolumn{8}{|c|}{ Legal Compliance Costs } \\
\hline$\%$ of Profit Before Tax & 0.66 & 1.14 & 0.34 & 1.62 & 0.24 & 0.80 & $0.7 s$ \\
\hline$\%$ of Tax Paid & 2.03 & 3.58 & 0.77 & 6.14 & 0.48 & 2.60 & $0.8 \varsigma$ \\
\hline \multicolumn{8}{|c|}{ Net Compliance Costs after Cash Flow Benefits of Advance Tax and Tax Deductibility } \\
\hline $\begin{array}{l}\% \text { of Legal Compliance } \\
\text { Costs }\end{array}$ & -17.08 & -41.93 & -144.35 & 9.29 & -193.61 & -77.54 & -1.1 \\
\hline$\%$ of Profit Before Tax & -0.11 & -0.48 & -0.49 & 0.15 & -0.47 & -0.28 & -1.0 \\
\hline$\%$ of Tax Paid & -0.35 & -0.45 & -1.08 & 0.33 & -0.94 & -0.50 & -1.1 \\
\hline \multicolumn{8}{|c|}{ Net Compliance Costs after Cash Flow Benefits of Advance Tax, Tax Deductibility and TDS } \\
\hline $\begin{array}{l}\% \text { of Legal Compliance } \\
\text { Costs }\end{array}$ & -18.48 & -75.48 & -162.55 & 5.62 & -209.14 & -92.01 & -1.0 \\
\hline$\%$ of Profit Before Tax & -0.12 & -0.86 & -0.56 & 0.09 & -0.51 & -0.39 & -0.91 \\
\hline$\%$ of Tax Paid & -0.37 & -1.65 & -1.22 & 0.10 & -1.01 & -0.83 & -0.8 \\
\hline
\end{tabular}


Table 11: Estimated Costs to Companies of Delayed Refunds in 2000-01

\begin{tabular}{lr}
\hline \multicolumn{1}{c}{ Item } & Cost \\
\hline Estimated delay costs (Rs Million) & 7531.8 \\
Corporation tax revenue in 2000-01 (Rs Million) & 356960 \\
Delayed refund cost as a \% of corporation tax revenue in 2000-01 & 2.11 \\
Memo & \\
Delayed refunds where costs could not be estimated & 670.8 \\
\hline (Amount refunded in Rs Million) & \\
\hline Basic data source: CAG (2002a).
\end{tabular}

Table 12: Aggregate Estimates of the Compliance Costs of Companies

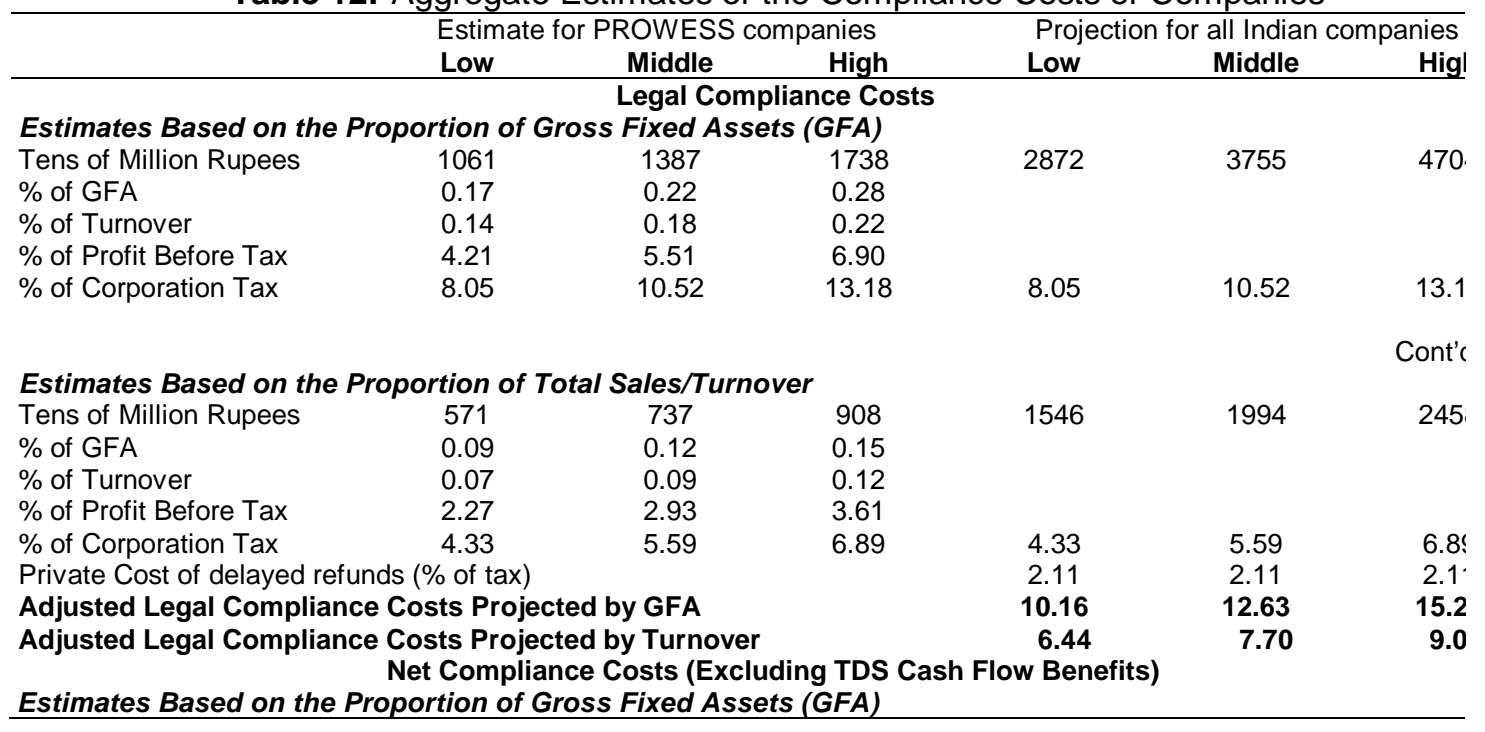


Table 12: Aggregate Estimates of the Compliance Costs of Companies

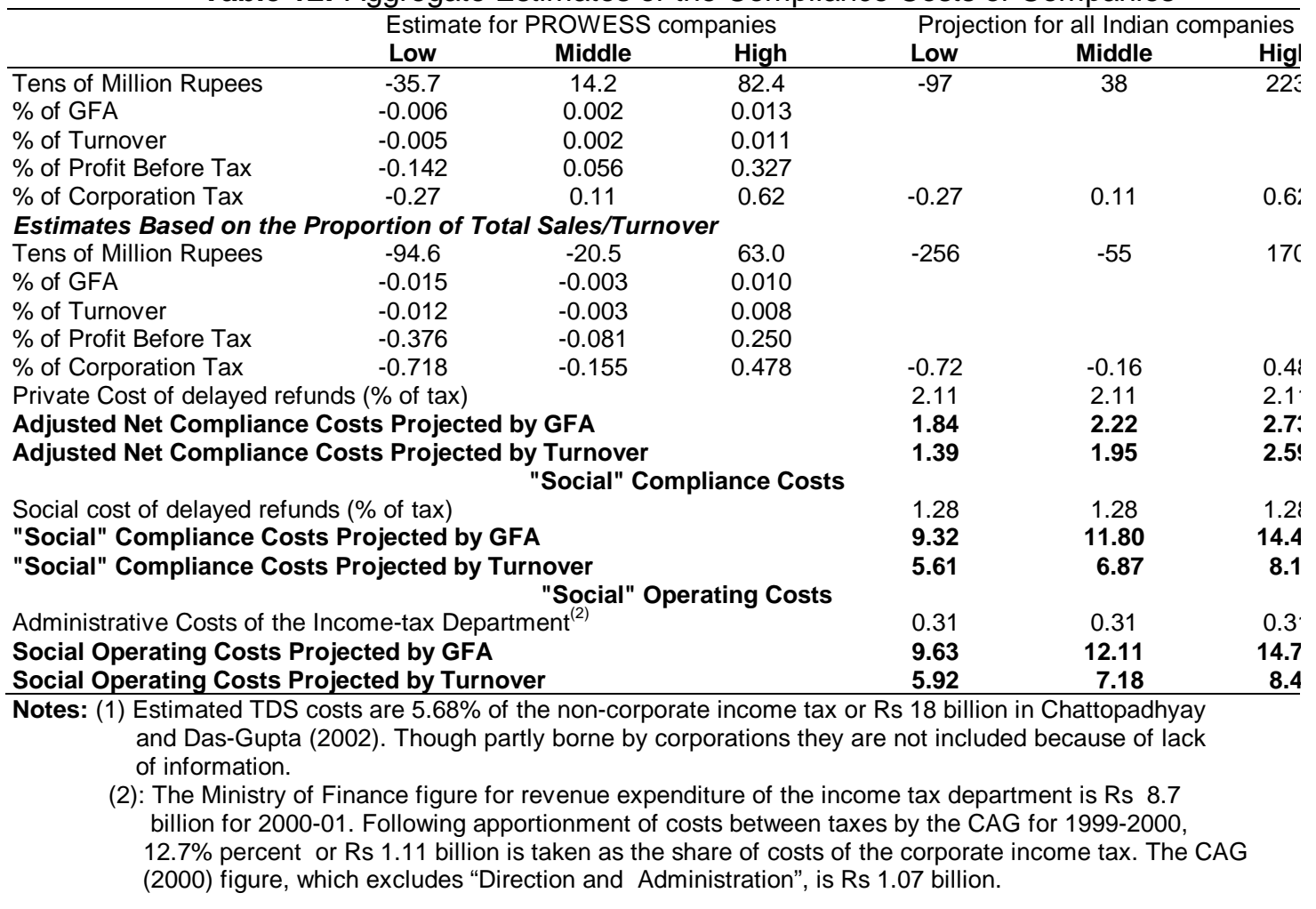


Table 13: Rating by Sample Companies of Selected Activities Contributing to Internal Cost (Figures in cells are the number of responding companies)

\begin{tabular}{lccccccc}
\hline & $\begin{array}{c}\text { Very } \\
\text { Important } \\
\text { (Score:4) }\end{array}$ & $\begin{array}{c}\text { Quite } \\
\text { Important } \\
\text { (Score:3) }\end{array}$ & $\begin{array}{c}\text { Average } \\
\text { (Score:2) }\end{array}$ & $\begin{array}{c}\text { Quite } \\
\text { unimportant } \\
\text { (Score:1) }\end{array}$ & $\begin{array}{c}\text { Unimportant } \\
\text { (Score:0) }\end{array}$ & $\begin{array}{c}\text { Can't } \\
\text { say }\end{array}$ & $\begin{array}{c}\text { Average } \\
\text { Score }\end{array}$ \\
\hline $\begin{array}{l}\text { Information asked for during } \\
\text { scrutiny assessment }\end{array}$ & 22 & 14 & 2 & 0 & 1 & 0 & 3.44 \\
$\begin{array}{l}\text { Maintaining account books } \\
\text { Completing and Submitting tax } \\
\text { returns }\end{array}$ & 15 & 3 & 3 & 0 & 1 & 0 & 3.41 \\
$\begin{array}{l}\text { Completing and Submitting } \\
\text { TDS returns }\end{array}$ & 21 & 11 & 6 & 0 & 0 & 0 & 3.39 \\
$\begin{array}{l}\text { To obtain a tax refund } \\
\text { Research and tax planning }\end{array}$ & 21 & 10 & 5 & 1 & 1 & 0 & 3.29 \\
$\begin{array}{l}\text { Tax related training for } \\
\text { employees }\end{array}$ & 15 & 17 & 6 & 0 & 0 & 1 & 3.24 \\
$\begin{array}{l}\text { Providing assistance to } \\
\text { employees }\end{array}$ & 0 & 6 & 13 & 1 & 4 & 1 & 2.18 \\
\hline
\end{tabular}

Table 14: Internal Compliance Costs by Object of Expenditure (Rs '000)

\begin{tabular}{lcccccr}
\hline & $\begin{array}{c}\text { Average } \\
\%\end{array}$ & Average & Minimum & Maximum & $\begin{array}{r}\text { Coefficient } \\
\text { of variation }\end{array}$ & $\begin{array}{r}\text { No } \\
\text { observ }\end{array}$ \\
\hline $\begin{array}{l}\text { On employee salaries, etc. } \\
\text { Office space/services at market }\end{array}$ & 24.7 & 656 & 10 & 5,000 & 1.65 & 3 \\
$\begin{array}{l}\text { rental value } \\
\begin{array}{l}\text { Computers and data processing } \\
\text { Accounts/record preparation, }\end{array}\end{array}$ & 11.8 & 313 & 1 & 2,400 & 1.93 & 3 \\
storage, etc. & 9.9 & 262 & 1 & 5,000 & 3.33 & 3 \\
& 8.0 & 214 & 1 & 4,000 & 3.24 & 3
\end{tabular}


Table 14: Internal Compliance Costs by Object of Expenditure (Rs '000)

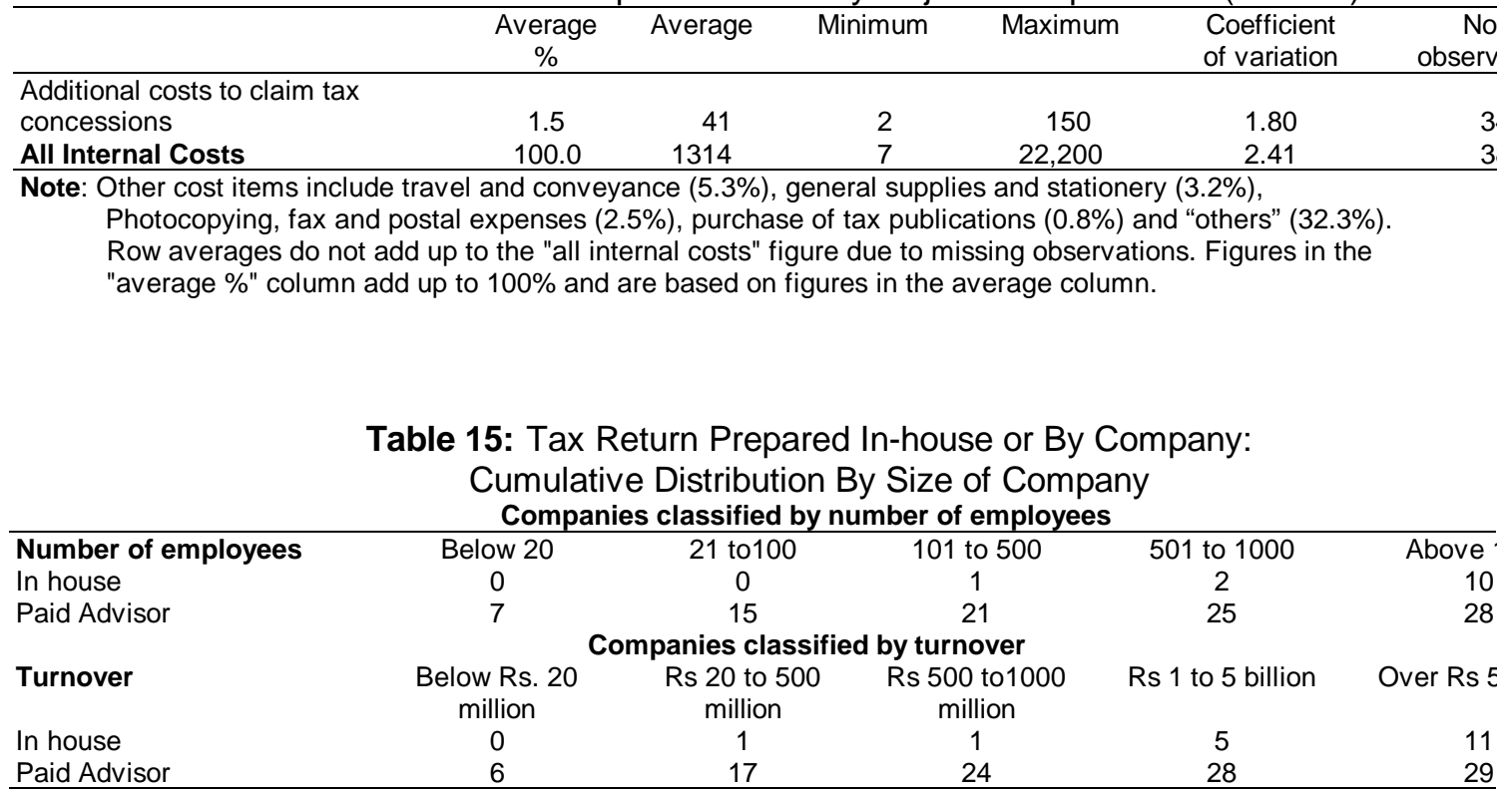


Table 16: Fees Paid to Tax Advisors*

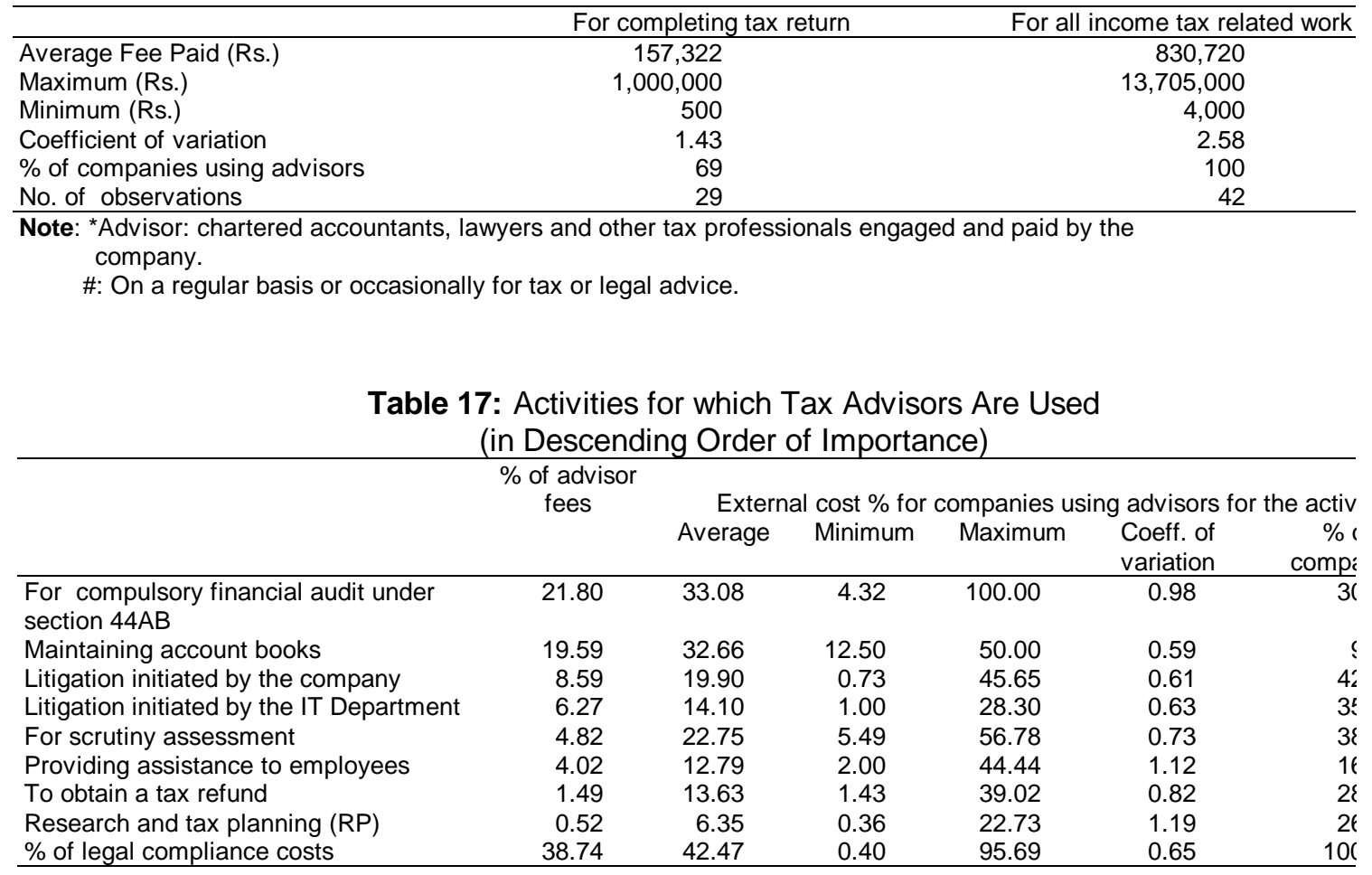


Table 18: Distribution By Company Size of Fees Paid to Tax Advisors for Income Tax Related Work (in Rupees)

Companies classified by number of employees

\begin{tabular}{|c|c|c|c|c|c|}
\hline No. of Employees & Below 20 & 21 to100 & 101 to 500 & 501 to 1000 & Above 10 \\
\hline Average & 230,715 & 160,938 & 196,071 & 767,725 & 1,19 \\
\hline Standard Deviation & 235,257 & 224,861 & 219,145 & 942,405 & 2,11 \\
\hline No. of Observations & 5 & 8 & 7 & 5 & \\
\hline \multicolumn{6}{|c|}{ Companies classified by turnover } \\
\hline Turnover & Below Rs. 20 million & $\begin{array}{c}\text { Rs } 20 \text { to } 500 \\
\text { million }\end{array}$ & $\begin{array}{c}\text { Rs } 500 \text { to } 1000 \\
\text { million }\end{array}$ & Rs 1 to 5 billion & Over Rs $5 k$ \\
\hline Average & 184,940 & 200,955 & 510,714 & 611,944 & 1,51 \\
\hline Standard Deviation & 239,624 & 254,109 & 736,594 & 517,490 & 2,75 \\
\hline No. of Observations & 5 & 11 & 7 & 8 & \\
\hline
\end{tabular}

Table 19: Reasons for Engaging a Tax Advisor

\begin{tabular}{|c|c|c|c|c|c|c|c|c|}
\hline & 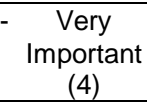 & $\begin{array}{c}\text { Quite } \\
\text { Important } \\
\text { (3) }\end{array}$ & $\begin{array}{c}\text { Average } \\
\text { (2) }\end{array}$ & $\begin{array}{c}\text { Quite } \\
\text { unimportant } \\
\text { (1) }\end{array}$ & $\begin{array}{c}\text { Unimpor- } \\
\text { tant } \\
(0)\end{array}$ & $\begin{array}{c}\text { No } \\
\text { Opinion }\end{array}$ & $\begin{array}{c}\text { Average } \\
\text { score }\end{array}$ & $\begin{array}{r}\text { Tc } \\
\text { respi }\end{array}$ \\
\hline Frequent changes of laws & 22 & 14 & 4 & 0 & 1 & 1 & 3.37 & $\angle$ \\
\hline For perfect tax calculation & 26 & 9 & 3 & 0 & 3 & 0 & 3.34 & $\angle$ \\
\hline Complex tax affairs to deal with & 6 & 15 & 11 & 2 & 6 & 1 & 2.33 & $\angle$ \\
\hline Limited in-house expertise & 8 & 10 & 11 & 3 & 6 & 3 & 2.29 & $\angle$ \\
\hline Lack of assurance about help & & & & & & & & $\angle$ \\
\hline from tax officials & 10 & 7 & 14 & 3 & 5 & 2 & 2.36 & \\
\hline To reduce tax burden & 5 & 12 & 13 & 2 & 8 & 1 & 2.10 & $\angle$ \\
\hline Others & 2 & 0 & 0 & 0 & 0 & 7 & 4.00 & \\
\hline
\end{tabular}


Table 20: Number of Assessment Years in Dispute

\begin{tabular}{|c|c|c|c|c|c|c|c|}
\hline Authority & Tax or penalty & Average & Minimum & Maximum & $\begin{array}{l}\text { Standard } \\
\text { deviation }\end{array}$ & $\begin{array}{c}\text { Coefficient of } \\
\text { variation }\end{array}$ & $\begin{array}{l}\text { Numb } \\
\text { respol }\end{array}$ \\
\hline \multirow{2}{*}{$\begin{array}{l}\text { Commissioner } \\
\text { (Appeals) }\end{array}$} & $\begin{array}{l}\text { For tax } \\
\text { For penalty or }\end{array}$ & 2.35 & 1 & 8 & 1.70 & 0.72 & $2 z$ \\
\hline & interest & 2.40 & 2 & 3 & 0.55 & 0.23 & 5 \\
\hline \multirow{2}{*}{$\begin{array}{l}\text { Income Tax } \\
\text { Appellate Tribunal }\end{array}$} & For tax & 5.33 & 1 & 14 & 4.13 & 0.77 & 21 \\
\hline & $\begin{array}{l}\text { For penalty or } \\
\text { interest }\end{array}$ & 2.25 & 1 & 4 & 1.26 & 0.56 & 4 \\
\hline \multirow[t]{2}{*}{$\begin{array}{l}\text { High Court/ } \\
\text { Supreme Court }\end{array}$} & $\begin{array}{l}\text { For tax } \\
\text { For penalty or }\end{array}$ & 2.95 & 1 & 10 & 2.69 & 0.91 & $1 C$ \\
\hline & interest & -- & -- & -- & -- & -- & 0 \\
\hline \multirow[t]{2}{*}{$\begin{array}{l}\text { Total Assessment } \\
\text { years }\end{array}$} & $\begin{array}{l}\text { For tax } \\
\text { For penalty or }\end{array}$ & 7.85 & 1 & 20 & 6.16 & 0.79 & $2 \epsilon$ \\
\hline & interest & 2.63 & 1 & 4 & 1.06 & 0.40 & 8 \\
\hline
\end{tabular}

Table 21: Legal Compliance Costs and Assessment Proceedings (Double-Log Regressions of Scaled Legal Compliance Costs in Rupees)

\begin{tabular}{lcc}
\hline Scaling (Size) variable & $\begin{array}{c}\text { Size coefficient for number of } \\
\text { assessment years }\end{array}$ & $\begin{array}{c}\text { Elasticity with respect to numb } \\
\text { assessment years }\end{array}$ \\
\hline Turnover (in Rs.) & 0.288 & 0.288 \\
Book Value of Assets (in Rs.) & 0.341 & 0.341 \\
Employment (in numbers) & $0.487^{*}$ & 0.487 \\
Profit Before Tax/Loss Index & $0.595^{\star * *}$ & 1.150 \\
Net Tax Paid Index & $0.579^{* *}$ & 1.119 \\
\hline
\end{tabular}

Note: Regressions are the same as in Table 7: R-square, observations and other coefficients are reported there as are notes on the regressions. 
Table 22: Voluntary Costs as a Percentage of Legal Compliance Costs

\begin{tabular}{lccc}
\hline & Average & Coefficient of variation & No. of observations \\
\hline Internal Voluntary Costs & 17.78 & 0.76 & 32 \\
External Voluntary Costs & 22.16 & 0.88 & 22 \\
Total Legal Voluntary Costs* & 19.11 & 0.91 & 38 \\
Total Voluntary Costs including "Others/Unallocated" & 19.99 & 0.82 & 32 \\
Internal Voluntary Costs & 43.08 & 0.71 & 22 \\
External Voluntary Costs & 24.73 & 0.89 & 38 \\
Total Legal Voluntary Costs & & \\
\hline Note: ${ }^{*}$ Average total costs are below both internal and external costs because of differing numbers of observations: If \\
component is missing, total voluntary costs are taken as equal to the other component.
\end{tabular}

Table 23: TDS Cash Flow Benefits of 5 Companies

\begin{tabular}{lccccccc}
\hline & Company & Company & Company & Company & Company & Average & Co $\epsilon$ \\
& $\mathrm{A}$ & $\mathrm{B}$ & $\mathrm{C}$ & $\mathrm{D}$ & $\mathrm{E}$ & & $\mathrm{V}_{i}$ \\
\hline Percentage of Tax Paid & 0.03 & 1.20 & 0.14 & 0.23 & 0.08 & 0.33 & 1. \\
Per Employee per Annum (in Rs) & 4.06 & 133.03 & 126.30 & 148.37 & 81.14 & 98.58 & 0. \\
\% of Profit Before Tax & 0.009 & 0.38 & 0.06 & 0.06 & 0.04 & 0.11 & 1. \\
\% of Legal Compliance Cost & 1.40 & 33.55 & 18.19 & 3.67 & 15.54 & 14.47 & 0. \\
\hline
\end{tabular}


Table 24: High Compliance Cost Income Tax Provisions

\begin{tabular}{lccccc}
\hline & Applicable & $\begin{array}{c}\text { Time taken: } \\
\text { High }\end{array}$ & $\begin{array}{c}\text { Time taken: } \\
\text { Average }\end{array}$ & $\begin{array}{c}\text { Time taken: } \\
\text { Low }\end{array}$ & $\begin{array}{c}\text { Average } \\
\text { Score }\end{array}$ \\
\hline TDS for non-employees & 42 & 18 & 18 & 4 & 2.4 \\
TDS for employees & 41 & 16 & 15 & 8 & 2.2 \\
Audit requirements u/s 44AB & 39 & 26 & 11 & 0 & 2.7 \\
Valuation of perquisites to employees & 39 & 17 & 10 & 8 & 2.3 \\
Minimum Alternate Tax (u/s 115JA/115JB) & 26 & 11 & 7 & 7 & 2.2 \\
Non-resident withholding (u/s 195 etc.) & 26 & 5 & 14 & 5 & 2.0 \\
Loss carry forward and set off & 22 & 6 & 11 & 3 & 2.2 \\
Claiming export benefits (u/s 80HHC, & 19 & 8 & 6 & 4 & 2.2 \\
80HHE, 10A/ 10B etc.) & 19 & 8 & 6 & 5 & 2.2 \\
International tax provisions & 18 & 9 & 4 & 4 & 2.3 \\
Others (Inconsistencies with Companies & & & & & \\
Act, depreciation provisions, establishment & & & & & \\
costs in connection with free trade zones) & & 7 & 4 & 6 & 2.1 \\
Tax collected at source & 17 & 7 & & & \\
\hline
\end{tabular}

*Notes: Time taken High $=3$, Time taken Average $=2$, Time taken Low $=1$. u/s: Under section. 
Table 25: Compliance Costs With Income Tax Provisions (\% of legal compliance cost)

\begin{tabular}{lcccccc}
\hline & Average & Minimum & Maximum & $\begin{array}{c}\text { Std dev. } \\
\end{array}$ & $\begin{array}{c}\text { Coeff. of } \\
\text { var. }\end{array}$ & $\begin{array}{c}\text { Ot } \\
\text { val }\end{array}$ \\
\hline $\begin{array}{l}\text { Audit Requirements u/s 44AB } \\
\text { Claiming export benefits (u/s 80HHC, }\end{array}$ & 13.26 & 0.005 & 30.00 & 8.48 & 0.64 & 2 \\
80HHE, 10A/ 10B etc.) & 10.04 & 0.005 & 30.00 & 9.82 & 0.98 & 1 \\
TDS for employees & 9.01 & 0.015 & 24.70 & 6.71 & 0.74 & $1:$ \\
TDS for non employees & 8.44 & 0.015 & 40.20 & 9.13 & 1.08 & $1:$ \\
International tax provisions & 6.75 & 2.000 & 15.00 & 5.68 & 0.84 & 4 \\
Loss carry forward and set off & 6.50 & 0.005 & 15.00 & 5.14 & 0.79 & $1:$ \\
Valuation of perquisites to employees & 6.25 & 0.040 & 20.00 & 5.15 & 0.82 & 1 \\
Income accruals & 5.50 & 1.000 & 10.00 & 3.72 & 0.68 & 11 \\
Non-resident withholding (u/s 195 etc.) & 5.37 & 0.040 & 10.00 & 3.93 & 0.73 & 1 \\
Minimum Alternate Tax (u/s & & & & & & \\
115JA/115JB) & 5.29 & 0.010 & 10.00 & 3.73 & 0.70 & 7 \\
All categories * & 46.96 & 0.070 & 100.00 & 26.86 & 0.57 & 2.
\end{tabular}

Notes: (1) u/s: Under section.

(2) *: Two categories, tax collection at source and inconsistencies with the Companies Act each contributing $4 \%$ to $5 \%$ of costs are not shown, The average figure in the total row is not the column sum due to missing observations. It has been computed from company by company totals.

Table 26: Compliance Requirements With Income Tax Administrative Procedures

\begin{tabular}{lcccrr}
\hline & Applicable & $\begin{array}{c}\text { Time taken- } \\
\text { High }\end{array}$ & $\begin{array}{c}\text { Time taken- } \\
\text { Average }\end{array}$ & $\begin{array}{c}\text { Time taken- } \\
\text { Low }\end{array}$ & $\begin{array}{r}\text { Averi } \\
\text { Scol }\end{array}$ \\
\hline Refunds & & 24 & 5 & 1 & 2.1 \\
Scrutiny assessment procedures & 33 & 22 & 6 & 4 & 2.1 \\
Accounting for TDS & 37 & 19 & 10 & 4 & 2.1 \\
Appeals and litigation & 36 & 17 & 7 & 4 & 2.1 \\
Completion and filing corporation tax return & 33 & 16 & 14 & 3 & 2. \\
Obtaining clearances, approvals, etc. from & 29 & 11 & 9 & 6 & 2.1 \\
IT authorities & & & &
\end{tabular}

IT authorities 
Table 26: Compliance Requirements With Income Tax Administrative Procedures

\begin{tabular}{lccccr}
\hline & Applicable & $\begin{array}{c}\text { Time taken- } \\
\text { High }\end{array}$ & $\begin{array}{c}\text { Time taken- } \\
\text { Average }\end{array}$ & $\begin{array}{c}\text { Time taken- } \\
\text { Low }\end{array}$ & $\begin{array}{r}\text { Aver: } \\
\text { Scol }\end{array}$ \\
\hline Accounting for IT purposes (u/s 132, 145A) & 25 & 8 & 9 & 5 & 2. \\
\hline
\end{tabular}

Note: ${ }^{*}$ Time taken - High $=3$, Average $=2$, Low $=1$.

Table 27: Cost of Compliance With Income Tax Administrative Procedures (\% of legal compliance cost)

\begin{tabular}{|c|c|c|c|c|c|c|}
\hline & Average & Minimum & Maximum & Std dev & $\begin{array}{l}\text { Coeff of } \\
\text { variation }\end{array}$ & $\begin{array}{l}\text { Obse } \\
\text { vatiol }\end{array}$ \\
\hline Appeals and litigation & 14.67 & 0.040 & 65.00 & 15.31 & 1.04 & 1 \\
\hline Scrutiny assessment procedures & 14.50 & 0.005 & 50.00 & 11.78 & 0.81 & 1 \\
\hline Refunds & 11.74 & 0.040 & 70.00 & 17.11 & 1.46 & 1 \\
\hline $\begin{array}{l}\text { Completing and filing corporation tax } \\
\text { return }\end{array}$ & 10.32 & 0.005 & 25.00 & 7.23 & 0.70 & 1 \\
\hline $\begin{array}{l}\text { Accounting for TDS } \\
\text { For clearances, approvals, etc. from }\end{array}$ & 9.47 & 0.005 & 25.00 & 6.75 & 0.71 & 1 \\
\hline $\begin{array}{l}\text { IT authorities } \\
\text { Accounting for IT purposes (u/s 132, }\end{array}$ & 6.51 & 1.000 & 15.60 & 4.57 & 0.70 & : \\
\hline $\begin{array}{l}145 \mathrm{~A}) \\
\text { All categories above }\end{array}$ & $\begin{array}{r}5.14 \\
43.07\end{array}$ & $\begin{array}{l}0.005 \\
0.020\end{array}$ & $\begin{array}{c}12.00 \\
100.00\end{array}$ & $\begin{array}{r}3.80 \\
25.85\end{array}$ & $\begin{array}{l}0.74 \\
0.60\end{array}$ & 2 \\
\hline
\end{tabular}

Note: *: The average figure in the total row is not the column sum. It has been computed from company by company totals. 
Table 28: Problems Identified By Respondents in Open Ended Questions Problem area

Slow Assessments/Appeals procedure at various level

Number of respond $\epsilon$

Complicated returns and complicated rules/lack of accountability in case of refunds/approvals mentioning proble

etc., delays in refunds/ follow up for refunds

Collection of TDS certificates from various customers and getting credit for the same (Note:

procedure now streamlined)

The complex scheme of the Act for granting allowances and disallowances, Complex maze of

provisions, concessions and rules

Delays in delivering orders/ tax orders

Lack of accountability and transparency in tax administration matters

9

Nontransparent and ambiguous terminology/tax laws.

Complexity in compliance with various procedures

Complex tax audit report

Need for elimination of tax categories both at Central and State level

Difficulty in compliance with transfer pricing regulations

Changes to extend the purview of prerequisites 


\section{Appendix}

\section{A. Response Rate}

For the mailed survey, a list of 3500 company addresses from all over the country was obtained from a large government data base of corporation tax assesses according to a locationally stratified random sample design. No other stratification criteria could be employed given the structure of the data base. Of this, 1000 addresses were fatally incomplete while in another 206 cases, questionnaires were returned by the post office because the address or addressee was unknown. Eleven trade associations and chambers of commerce were also contacted and 1200 questionnaires handed over to their office bearers to distribute to members with covering letters from the associations themselves. Despite two rounds of reminders the response rate remained low. So a further 200 questionnaires were distributed after personal contact with companies in Mumbai. This generated the bulk of responses (28 out of 45 usable responses). As a result, the sample, though conceived as an anonymous stratified random sample, degenerated into a "convenience" sample. The eventual net response rate, excluding unusable responses, was an unsatisfactory 1.15 percent. 
Table A1: Questionnaires Mailed to Individuals and Responses Received

\begin{tabular}{lcc}
\hline & Numbers & $\begin{array}{c}\% \text { of initial } \\
\text { sample }\end{array}$ \\
\hline Addresses received from database & 3500 & 74.47 \\
$\quad$ of which addresses found incomplete & 1000 (approx.) & 21.28 \\
Net received & 2500 (approx.) & 53.19 \\
Add questionnaires mailed or hand delivered to industry associations & 1200 & 25.53 \\
Total addresses available/ questionnaires mailed or hand delivered to & 3700 (approx.) & 78.72 \\
industry associations & 206 & 4.38 \\
Number not deliverable by post offices & & 4.26 \\
Memo: & 200 & 28 \\
Questionnaires hand delivered after individual contact & & \\
$\quad$ of which responses received & &
\end{tabular}

\section{B. Basic Characteristics of Companies in the Sample}

Table A2: Basic Company Information

\begin{tabular}{|c|c|c|c|c|c|}
\hline \multicolumn{6}{|c|}{ Location } \\
\hline Location & Delhi & Mumbai & Other Metro & Others & Total \\
\hline Companies & 2 & 32 & 5 & 4 & 43 \\
\hline \multicolumn{6}{|c|}{ Year of Establishment } \\
\hline Year & Till 1947 & 1948 to 1960 & 1961 to 1970 & 1971 to 1980 & After 1980\# \\
\hline Companies & 7 & 4 & 3 & 5 & 22 \\
\hline
\end{tabular}

Note: \# There are 15 companies, which were established in 1991 or thereafter. 


\begin{tabular}{|c|c|c|c|c|c|}
\hline \multicolumn{6}{|c|}{ Age of Companies (Years) } \\
\hline Average & Minimum & Maximum & \multicolumn{2}{|c|}{ Stand. dev. } & No. of Observati \\
\hline 27.0 & 1 & 88 & \multicolumn{2}{|c|}{24.5} & 41 \\
\hline \multicolumn{6}{|c|}{ Employee Strength (Numbers) } \\
\hline Full Time Employees & Below 20 & 21 to 100 & 101 to 500 & 501 to 1000 & Above 1001 \\
\hline Companies & 8 & 7 & 7 & 5 & 13 \\
\hline Average & Minimum & Maximum & \multicolumn{2}{|c|}{ Stand. dev. } & No. of Observati \\
\hline 2240.48 & 2 & 23539 & \multicolumn{2}{|c|}{4504.9} & 40 \\
\hline $\begin{array}{l}\text { Part time Employees } \\
\text { (in equivalent full time } \\
\text { employees) }\end{array}$ & 0 & 1 to 25 & 26 to 50 & 51 to 200 & 201 and above \\
\hline Companies & 21 & 5 & 4 & 3 & 4 \\
\hline Average & Minimum & Maximum & \multicolumn{2}{|c|}{ Stand. dev. } & No. of Observati \\
\hline 2004 & 1 & 30000 & \multicolumn{2}{|c|}{7468.1} & 37 \\
\hline \multicolumn{6}{|c|}{ Book Value of Assets (Rs. million) } \\
\hline Book Value & Below 10 & 10 to 200 & 200 to 500 & 500 to 1000 & Over 1000 \\
\hline Companies & 10 & 8 & 7 & 7 & 9 \\
\hline Average & Minimum & Maximum & \multirow{2}{*}{\multicolumn{2}{|c|}{$\begin{array}{l}\text { Stand. dev. } \\
310089\end{array}$}} & No. of Observati \\
\hline 100923 & 15 & 1559436 & & & \\
\hline \multicolumn{6}{|c|}{ Turnover (Rs. million) } \\
\hline Turnover & Below 20 & 0 to 500 & 500 to 1000 & 1000 to 5000 & Over 500 \\
\hline Companies & 6 & 12 & 7 & 8 & 8 \\
\hline
\end{tabular}




\begin{tabular}{|c|c|c|c|c|c|}
\hline & & Minimum & Maximum & Stand. dev. & $\begin{array}{c}\text { No. of Observati } \\
41\end{array}$ \\
\hline \multicolumn{6}{|c|}{ Profit Before Tax or PBT (Rs million) } \\
\hline $\begin{array}{l}\text { Profit } \\
\text { Loss }\end{array}$ & $\begin{array}{c}\text { Average } \\
1964.9 \\
-2387 \\
\end{array}$ & $\begin{array}{c}\text { Minimum } \\
0.004 \\
-7600\end{array}$ & $\begin{array}{c}\text { Maximum } \\
25670 \\
-40.7\end{array}$ & $\begin{array}{c}\text { Stand. dev. } \\
5525.1 \\
3460\end{array}$ & $\begin{array}{c}\text { No. of Observati } \\
34 \\
6\end{array}$ \\
\hline
\end{tabular}

\section{Compliance Costs and Company Size: Tables}

Table A3: Legal Compliance Costs as a Percentage of Turnover

\begin{tabular}{lccccc}
\hline \multicolumn{1}{c}{ Turnover } & $\begin{array}{c}\text { Below Rs. } 20 \\
\text { million }^{@}\end{array}$ & $\begin{array}{c}\text { Rs } 20 \text { to } 500 \\
\text { million }\end{array}$ & $\begin{array}{c}\text { Rs } 500 \text { to } 1000 \\
\text { million }\end{array}$ & Rs 1 to 5 billion & Over Rs! \\
\hline Average & 1.28 & 0.40 & 0.16 & 0.13 \\
Coefficient of Variation & 0.69 & 0.95 & 0.77 & 1.26 \\
No of observations & 4 & 12 & 7 & 8 \\
\hline
\end{tabular}

Note: @: Excludes one outlier.

Table A4: Legal Compliance Costs Per Employee (in Rupees)

\begin{tabular}{|c|c|c|c|c|c|}
\hline No. of Employees & Below 20@ & 21 to 100 & 101 to 500 & 501 to 1000 & Above \\
\hline Average & 20138 & 11818 & 2335 & 3729 & \\
\hline Coeff. of Variation & 0.69 & 1.19 & 0.69 & 0.99 & \\
\hline No. of observations & 4 & 8 & 7 & 5 & \\
\hline
\end{tabular}

Note: @: Excludes two outliers. 
Table A5: Legal Compliance Costs as a Percentage of Book Value of Assets

\begin{tabular}{lccccc}
\hline \multicolumn{1}{c}{ Book value of assets } & $\begin{array}{c}\text { Below Rs. 20 } \\
\text { million }\end{array}$ & $\begin{array}{c}\text { Rs } 20 \text { to } 500 \\
\text { million }\end{array}$ & $\begin{array}{c}\text { Rs } 500 \text { to } 1000 \\
\text { million }\end{array}$ & Rs 1 to 5 billion & Over Rs! \\
\hline Average & 4.17 & 0.97 & 0.33 & 0.46 \\
Coefficient of Variation & 0.70 & 1.30 & 0.82 & 1.28 \\
No of observations & 7 & 14 & 7 & 2 \\
\hline
\end{tabular}

Note: @: Excludes three outliers.

Table A6: Legal Compliance Costs as a Percentage of Profit Before Tax

\begin{tabular}{lcccccr}
\hline \multicolumn{1}{c}{ Profit before tax } & $\begin{array}{c}\text { Loss making } \\
\text { companies }^{*}\end{array}$ & $\begin{array}{c}\text { Below Rs. 20 } \\
\text { million* }^{*}\end{array}$ & $\begin{array}{c}\text { Rs 20 to 500 } \\
\text { million }\end{array}$ & $\begin{array}{r}\text { Rs 500 to1000 } \\
\text { million }\end{array}$ & $\begin{array}{r}\text { Rs 1 to 5 billion } \\
\text { Ovel } \\
\text { bil }\end{array}$ \\
\hline $\begin{array}{l}\text { Average } \\
\text { Coefficient of Variation }\end{array}$ & 1.71 & 8.38 & 2.20 & 0.22 & 0.17 \\
Number of observations & 1.03 & 1.00 & 1.21 & N.A. & 0.88 \\
\hline
\end{tabular}

Note: *Excludes one outlier and one zero-profit company.

Table A7: Legal Compliance Costs as a Percentage of Income Tax Paid

\begin{tabular}{lrrrrrr}
\hline Income tax paid & Negative net tax ${ }^{@}$ & $\begin{array}{r}\text { Below Rs. } 1 \\
\text { million }^{\#}\end{array}$ & $\begin{array}{r}\text { Rs 1 to 10 } \\
\text { million }\end{array}$ & $\begin{array}{r}\text { Rs 10 to 250 } \\
\text { million }\end{array}$ & $\begin{array}{r}\text { Rs 250 to } \\
1000 \text { million }\end{array}$ & $\begin{array}{r}\text { Ove } \\
\text { bi }\end{array}$ \\
\hline Average & -22.87 & 164.18 & 17.55 & 12.40 & 0.59 \\
Coefficient of Variation & 0.51 & 1.01 & 0.93 & 1.65 & 0.37 & 2 \\
Number of observations & 2 & 6 & 12 & 10 & 2 & 2 \\
\hline
\end{tabular}

Note: @: Excludes one outlier. \#: Excludes one outlier. 


\section{The Size of Tax Returns and Compliance Costs}

Though regression analysis for the current sample does not statistically support this, the number of pages of documents submitted with tax returns has been identified in the literature as a useful summary indicator of compliance costs (see Pope and Fayle, 1991). Sample information is summarised in Table A8. There is a wide variation in the average number of pages of documents submitted by companies, with the number ranging between 9 and 3100 . This is only partly linked to company size. Scanty information available suggests that the average is comparable to that in some countries with complex corporation tax codes.

Table A8: Pages of Documents Submitted by the Company with its Income Tax Return

\begin{tabular}{lc}
\hline & Number of Pages \\
\hline Average & 326 \\
Minimum & 9 \\
Maximum & 3100 \\
Standard Deviation & 541 \\
Number of observations & 41 \\
\hline
\end{tabular}

\section{E. The Tax Cost to Companies of CAG Audit objections}

Incorrect application of various tax provisions by the tax officials burdens taxpayers who have their tax assessments revisited. Costs associated with reopened assessments are implicitly reflected in reported costs in this study though no separate estimates are available. By examining the most expensive and most frequent mistakes made by tax officials, additional information can be gained about problem areas. Here objections by the Comptroller and Auditor General regarding incorrect assessments by the income tax department - which almost always lead to reopening of assessments - are reviewed.

In Table A9 the number and value of major audit objections by the CAG in 2000-01 are summarised. The most serious problem is with valuation of closing stocks of companies followed by the portmanteau category "underassessment". Both of these are areas where a good deal of discretion is available to assessing officers. Audit objections are made when mistakes come to light during annual test checks by auditors. However no information is available in CAG (2002) on the total number of test checks carried out, though this was reported in previous years. 
Given that only a small proportion of cases are externally audited, in many cases mistakes probably do not come to light. Of the next 4 categories in the table, items 3 to 6 , three deal with areas where the tax law is known to be complex and so could largely reflect genuine mistakes by assessing officers which can be remedied by training. While only internal evaluation of lapses can shed light on their causes, areas where additional training is needed for income tax officials - or areas which they deliberately ignore - are presumably reflected in their mistakes. 
Table A9: Audit Objections By the CAG and Their Tax Effect: 2000-01 (in Rs. Million)

\begin{tabular}{|c|c|c|c|c|}
\hline Nature of Objection & $\begin{array}{c}\text { Under } \\
\text { estimation of } \\
\text { income }\end{array}$ & $\begin{array}{c}\text { Over } \\
\text { estimation of } \\
\text { expenditure }\end{array}$ & Tax effect & Number of cases \\
\hline Incorrect valuation of closing stock & & 5633.2 & 5633.2 & 20 \\
\hline Underassessment of income and tax & 450.6 & 660.9 & 1111.4 & 92 \\
\hline $\begin{array}{l}\text { Incorrect computation of income of financial } \\
\text { corporations or business income }\end{array}$ & 788.8 & & 788.8 & 67 \\
\hline Incorrect carry forward/set off of losses & & 753.3 & 753.3 & 65 \\
\hline Over-assessment of income and tax & 737.5 & & 737.5 & 23 \\
\hline Irregular allowance of depreciation/ incorrect & & & & \\
\hline rates of depreciation applied & & 591.0 & 591.0 & 67 \\
\hline Other types of incorrect assessment of taxes ${ }^{*}$ & & & 984.0 & 55 \\
\hline $\begin{array}{l}\text { Total } \\
\text { Memo: }\end{array}$ & & & 10599.2 & 389 \\
\hline Total tax effect of all audit objections & & & 12883.8 & 618 \\
\hline $\begin{array}{l}\text { Total tax effect as a percentage of } \\
\text { corporate income tax collections }\end{array}$ & & & 3.6 & \\
\hline $\begin{array}{l}\text { Notes: * Irregular exemption; Excess deductio } \\
\text { Incorrect allowance of relief in respec } \\
\text { deduction of profits derived from servi } \\
\text { Detailed explanation of items in the ta } \\
\text { Source:CAG (2002) }\end{array}$ & $\begin{array}{l}\text { Chapter VIA; } \\
\text { fits from expor } \\
\text { vided to foreig } \\
\text { Chattopadhy }\end{array}$ & $\begin{array}{l}\text { orrect allowan } \\
\text { usiness; Mista } \\
\text { urists. } \\
\text { and Das-Gupt }\end{array}$ & $\begin{array}{l}\text { deduction; } \\
\text { allowance of } \\
\text { 02) . }\end{array}$ & \\
\hline
\end{tabular}




\section{References}

Allers, Marteen 1994. "Tax Compliance Costs in the Netherlands" in Cedric Sandford (ed.), Tax Compliance Costs Measurement and Policy. Bath, UK: Fiscal Publications.

Allingham, Michael G., and Agnar Sandmo, 1972. "Income Tax Evasion: A Theoretical Analysis", Journal of Public Economics, 1: 323-338.

Ariff, Mohammed, A.L.C. Loh, and A.A. Talib, 1995. "Compliance Cost of Corporate Taxation in Singapore, 1994, Accounting Research Journal, 8 : 75-87.

Ariff, M, A.L.C. Loh, and Z. Ismail, 1997. "Compliance Cost of Corporate Income Taxation in Singapore" Journal of Business, Finance and Accounting, 29: 1253-1268.

Binh, Tran-Nam et.al., 2000. "Tax Compliance Research: Research Methodology and Empirical Evidence from Australia, National Tax Journal, 53: 229-251.

Blumenthal, Marsha and Joel B. Slemrod, 1995. "The Compliance Cost of Taxing Foreign-Source Income: Its Magnitude, Determinants, and Policy Implications", International Tax and Public Finance, 2: 37-53.

Blumenthal, Marsha and Joel B. Slemrod 1996. "The Income Tax Compliance Cost Big Business", Public Finance Quarterly, 24: 411-438.

Centre for Monitoring the Indian Economy (CMIE), 1997. Prowess User's Manual, Volume 2, Data Definitions, Mumbai: CMIE.

2002. Corporate Sector, May 2002, Mumbai: CMIE (and on-line PROWESS data base).

Chan, S.Y.S, D.K.C. Cheung and M. Ariff, 1999. "Compliance Cost of Corporation Taxation in Hong Kong", International Tax Journal, 25: 4268. 
Chattopadhyay, Saumen and Arindam Das-Gupta, 2002. "The Income Tax Compliance Cost Of Indian Corporations", New Delhi, National Institute of Public Finance and Policy (mimeo). Available at http://www.planingcommission.nic.in/reports.

Chattopadhyay, Saumen and Arindam Das-Gupta, (2002a), "The compliance cost of the personal income tax and its determinants". New Delhi, National Institute of Public Finance and Policy (mimeo) Available at http://www.planingcommission.nic.in/reports.

Collard, David and Michael Godwin, 1999. "Compliance Costs for Employers: UK PAYE and National Insurance, 1995-96", Fiscal Studies (1999), 20: 423-449.

Comptroller and Auditor General (CAG), Government of India 2001. Report of the Comptroller and Auditor General of India for the year ended March, 2000, Union Government (Direct Taxes), No. 12 of 2000: Delhi: CAG.

2002. Report of the Comptroller and Auditor General of India for the year ended March, 2001, Union Government (Direct Taxes), No. 12 of 2001. Delhi: CAG.

2002. Report of the Comptroller and Auditor General of India for the year ended March, Union Government (Direct Taxes), Systems Appraisals No. 12A of 2001 Delhi: CAG.

Confederation of Indian Industry (CII), 2000. "Final Report on Survey of the Indian Business Environment as part of The World Business Environment Survey Measuring Conditions for Business Operation and Growth", submitted to the World Bank (including data set) New Delhi: CII.

Erard, Brian 1997. "The Income Tax Compliance Burden on Canadian Big Businesses", Working Paper 97-2, Technical Committee on Business Taxation, Department of Finance, Canada (available at http://www.finance.gc.ca).

1997a. "The Income Tax Compliance Burden on Small and Medium-Sized Canadian Businesses", Working Paper 97-12, Technical Committee on Business Taxation, Department of Finance, Canada (available at http://www.finance.gc.ca). 
Evans, Chris and Michael Walpole 1997. "Compliance Costs and Taxation Impact Statements", Australian Tax Forum, 13: 227-274.

Export-Import Bank of India 1998. "Transactions Costs of Indian Exports: An Analysis", Occasional Paper No. 64, Bombay: Export-Import Bank of India.

Fischer, Lutz 1989. "National Report, Germany", in Studies in International Fiscal Law: Administrative and Compliance Costs of Taxation, Cahiers De Droit Fiscal International, Volume 74b. Rio De Janeiro: International Fiscal Association.

Freidkes, Nahum and Moshe Gavish 1989."National Report, Israel", in Studies in International Fiscal Law: Administrative and Compliance Costs of Taxation, Cahiers De Droit Fiscal International, Volume 74b. Rio De Janeiro: International Fiscal Association.

Gerade, Marcel, Pascale Blondiaux, and Carine Vanden Berghe "National Report, Belgium", Studies in International Fiscal Law: Administrative and Compliance Costs of Taxation, Cahiers De Droit Fiscal International, Volume 74b. Rio De Janeiro: International Fiscal Association.

Government of India, Ministry of Finance and Company Affairs 2002. "Task Force on Direct Taxes: Consultation Paper" (Chairman: Vijay Kelkar processed). New Delhi: Government of India, Ministry of Finance and Company Affairs. (abbreviated "Kelkar Committee" in this report).

Gunz, Sally, Alan Macnaughton, and Karen Wensley, 1995 "Measuring the Compliance Cost of Tax Expenditures: The Case of Research and Development Incentives", Canadian Tax Journal, 43: 2008-2034.

Harris, I.W. 1989. "National Report, Hong Kong", in Studies in International Fiscal Law: Administrative and Compliance Costs of Taxation, Cahiers De Droit Fiscal International, Volume 74b. Rio De Janeiro: International Fiscal Association.

Hite, Peggy A and Adrian J. Sawyer, 1997. "A Comparison of Compliance Cost Estimates for the Tax System in the United States and New Zealand", International Bureau of Fiscal Documentation, February: 93-97. 
Hudson, John and Michael Godwin, 2000. "The Compliance Costs of Collecting Direct Tax in the UK: An Analysis of PAYE and National Insurance", Journal of Public Economics, 77: 29-44.

Imhof, F.W. 1989. "National Report, Netherlands", in Studies in International Fiscal Law: Administrative and Compliance Costs of Taxation, Cahiers De Droit Fiscal International, Volume 74b. Rio De Janeiro: International Fiscal Association.

International Fiscal Association, 1989. Studies in International Fiscal Law: Administrative and Compliance Costs of Taxation, Cahiers De Droit Fiscal International, Volume: 74b. Rio de Janeiro:, International Fiscal Association.

Loh A.L.C., et.al., 1997. "Compliance Costs of Corporate Income Taxation in Malayasia, 1995", Pacific Accounting Review, 9: 27-42.

Maddala, G.S. 1983. Limited-Dependent and Qualitative Variables in Econometrics . Cambridge: Cambridge University Press.

Malmer, Hakan 1995. "The Swedish Tax Reform in 1990-1991 and Tax Compliance Costs in Sweden", in Cedric Sandford, (ed.), Tax Compliance Costs Measurement and Policy, Bath. U.K.: Fiscal Publications in association with The Institute for Fiscal Studies.

Matheu, Luis Maria and C.P. Angel Gustavo Secchi, 1989. "National Report, Argentina", in Studies in International Fiscal Law: Administrative and Compliance Costs of Taxation, Cahiers De Droit Fiscal International, Volume 74b. Rio De Janeiro: International Fiscal Association.

, 1989. "National Report, Argentina", in Studies in International Fiscal Law: Administrative and Compliance Costs of Taxation, Cahiers De Droit Fiscal International, Volume 74b. Rio De Janeiro: International Fiscal Association.

Mikesell, John L. 1996. "Federal Individual Income Tax Collection Costs: The Burden of Compliance and Administration", in Richard, W. Lindholm, (ed.) Examination of Basic Weaknesses of Income as the Major Federal Tax Base. New York: Praeger Publishers. 
Mills, Lillian F 1996. "Corporate Tax Compliance and Financial Reporting", National Tax Journal, 49: 421-435.

Nicolaissen, Rolf H. 1989. "National Report, Norway", in Studies in International Fiscal Law: Administrative and Compliance Costs of Taxation, Cahiers De Droit Fiscal International, Volume 74b. Rio De Janeiro: International Fiscal Association.

Norrman, Bo and Hakan Malmer, 1989. "National Report, Sweden", in Studies in International Fiscal Law: Administrative and Compliance Costs of Taxation, Cahiers De Droit Fiscal International, Volume 74b. Rio De Janeiro: International Fiscal Association.

Plamondon, Robert E and David Zussman, 1998. "The Compliance Costs of Canada's Major Tax Systems and the Impact of Single Administration", Canadian Tax Journal, 46: 761-785.

Pope, Jeff. 1993a. "Policy Implications Arising from Compliance Costs of Taxation Research", Australian Tax Office (ATO) Conference, Canberra (November).

---1994. "Compliance Costs of Taxation: Policy Implications", Australian Tax Forum, 11: 85-121.

1995. "Tax Compliance Costs of Major Taxes in Australia" in Cedric Sandford, (ed.), Tax Compliance Costs: Measurement and Policy. Bath, UK: Fiscal Publications.

Pope, Jeff and Richard Fayle, 1991. "The Compliance Costs of Public Companies' Income Taxation in Australia 1986/87: Empirical Results", Australian Tax Forum, 8: 485-538.

Pope, Jeff, Richard Fayle, and D.L. Chen, 1993. "The Compliance Costs of Employment Related Taxation in Australia (Employers' Pay-As-YouEarn, Fringe Benefits Tax, Prescribed Payments System and Payroll Tax, 1989/90)", Economic Research Centre, The University of Australia (January).

1991. "The Compliance Costs of Public Companies' Income Taxation in Australia, 1986/87", Research Study No. 13, Australian Tax Research Foundation, Sydney, Australia. 
, 1994. "The Compliance Costs of Companies' Income Taxation in Australia" Australian Tax Research Foundation, Sydney, Australia.

Porter, Brenda A. 1999. "Survey of In-House Tax Departments in United Kingdom Corporates", British Tax Review, 4: 32-51.

Sandford, Cedric 1994. "International Comparisons of Administrative and Compliance Costs of Taxation". Australian Tax Forum, 11: 291-309.

Sandford, Cedric and John Hasseldine, 1992. "The Compliance Costs of Business Taxes in New Zealand", Wellington (N.Z), Institute of Policy Studies, (Executive Summary).

Sandford, Cedric, Michael Godwin, and Peter Hardwick, 1989 Administrative and Compliance Costs of Taxation. Bath, UK: Fiscal Publications.

Seltzer, David R. 1997. "Federal Income Tax Compliance Costs: A Case Study of Hewlett-Packard Company", National Tax Journal, 50: 487-493.

Slemrod, Joel 1995. "The Simplification Potential of Alternatives to Income Tax." Tax Note, 66: 1331-1340 (27 February).

Slemrod, Joel and Marsha Blumenthal, 1996. "The Income Tax Compliance Cost of Big Business", Public Finance Quarterly, 24: 411438.

Slemrod, Joel and Varsha Venkatesh, 2002. "The Income Tax Compliance Cost of Large and Mid-Sized Business" (A Report to the IRS LMSB Division), Office of Tax Policy Research, University of Michigan Business School, Ann Arbor.

Sridharan, J. 1999. "What It Costs to Operate the Indian Customs and Central Excise Duties?", Management and Accounting Research Journal (Institute of Chartered Accountants, Delhi), 2: 27-42 (May-June).

Talib, Amin Ali 1996. "The Compliance Costs of Taxation", Bulletin for International Fiscal Documentation, 50: 418-421 (September). 
Tan, L.M. and Tooley, S 1994. "Tax Simplification: Progress to Date", Bulletin for International Fiscal Documentation, 48: 236-38 (May).

Vaillancourt, Francois 1987. "The Compliance Costs of Taxes on Business and Individuals: A Review of the Evidence", Public Finance, 395-414.

Vaillancourt, Francois and Robert J. Reid, 1989. "National Report, Sweden", Studies in International Fiscal Law: Administrative and Compliance Costs of Taxation, Cahiers De Droit Fiscal International, Volume 74b. Rio De Janeiro: International Fiscal Association.

Wallschutzky lan G. and Brian Gibson, 1993. "Small Business Cost of Tax Compliance", Australian Tax Forum, 10.

Walpole, Michael, et.al., 1999 "Taxation Compliance Costs: Some Lessons from "Down-under", British Tax Review, 4: 244-271. 